\title{
CAR-T immunotherapies: biotechnological strategies to improve safety, efficacy and clinical outcome through CAR engineering
}

\section{Theano I. Panagopoulou ${ }^{1}$ and Qasim A. Rafiq ${ }^{1}$}

${ }^{1}$ Advanced Center for Biochemical Engineering, University College London, Gower Street, London, WC1E 6BT, UK

\begin{abstract}
$\mathrm{T}$ cells engineered to express a chimeric antigen receptor (CAR) have re-shaped the way hematological malignancies are treated. Despite the overwhelming early clinical success, CAR-T therapies are associated with severe side-effects, disease relapse and often exhibit limited efficacy. In this Review article we summarize the most recent biotechnological advances that have been developed to enhance the efficacy and specificity of CAR-T therapies, as well as to address the key challenges associated with them. We place particular emphasis on the most recent clinical data that indicate which CAR-T populations are the most relevant to clinical success, and indicate how the molecular structure of the CAR receptor can affect clinical outcome. Finally, we outline what we believe is the next generation of immunotherapies.
\end{abstract}

Keywords: chimeric antigen receptor, immunotherapy, biotechnology 


\section{Introduction}

Two autologous chimeric antigen receptor (CAR)-T cell therapies (Kymriah and Yescarta) were recently licensed by American and European agencies (FDA and EMA respectively). CAR-T cell therapies are a type of cancer immunotherapy in which a patient's $T$ cells are genetically engineered in the laboratory so they can attack cancer cells. Both licensed products target CD19, an antigen expressed on B cells and leukemic cells. Kymriah (tisagenlecleucel) brought to market by Novartis and Yescarta (axicabtagene ciloleucel) brought to market by Kite Pharma/ Gilead, are indicated for the treatment of pediatric and relapse/refractory (R/R) B cell acute lymphoblastic leukemia (B-ALL) and certain lymphoma subtypes and adult refractory diffuse large B cell lymphoma (R/DLBCL) respectively. Remarkably, the overall response rate in the short term was $83 \%$ based on a single dose of Kymriah with patients entering into remission within 3 months of being treated (Grupp, 2018; Maude et al., 2018, 2014) (ELIANA, NCT02435849) (Table 2), extending to 76\% and 70\% at 12 months and 18 months respectively (Grupp, 2018). Similarly, the recipients of Yescarta had an overall response rate of 71\% within 3 months (Locke et al., 2018, 2015; Neelapu et al., 2017) (ZUMA, NCT02348216) and 39\% of patients remained in remission for 27 months (Locke et al., 2018; Neelapu, 2018).

Although CAR-T therapies have a remarkable life-saving potential they are nevertheless associated with severe toxicities (most notably cytokine release syndrome and neurotoxicities), high cost (>£200,000) and limited efficacy on cancers other than blood malignancies. Furthermore, despite the high short-term response rates a proportion of patients relapse after CAR-T treatment. As a result, further understanding of $\mathrm{T}$ and CAR-T cell biology is required in order to improve these immunotherapies.

The immune system is comprised of the innate and adaptive systems. While the innate system is the first line of defense and is poised to act rapidly, the adaptive system displays immunological memory and contains cells such as $\mathrm{T}$ and $\mathrm{B}$ cells that are highly specific for any pathogenic threat. T cells are defined by the expression of the T cell receptor (TCR) which interacts with the Major Histocompatibility Complex (MHC) (also termed human leukocyteassociated [HLA] antigens), found on the surface of antigen presenting cells (APCs) such as dendritic cells (DC). This interaction is necessary for the recognition of the pathogenic threat by the $\mathrm{T}$ cell and its subsequent activation (Figure 1). The immunogenic response elicited by the T cell is dependent on the type of MHC that is presented by the APC (class I MHC or class II MHC), which subsequently defines whether the T cell will differentiate into one of the two major $\mathrm{T}$ cell subsets, CD8+ (T cytotoxic) or CD4+ (T helper). While most $\mathrm{T}$ cells disappear after the threat has been eliminated, others will survive and form memory cells that can survive for years. Memory T cells are classified according to the expression of certain surface markers (Table 1) (Gattinoni et al., 2011, 2009; Gebhardt et al., 2009; Hofmann and Pircher, 2011; Lugli et al., 2013; Masopust et al., 2010; Sallusto et al., 1999).

This review outlines the challenges associated with CAR-T immunotherapies and focuses on the most recent biotechnological and genomic engineering advancements that have been developed in order to address such challenges. Furthermore the review summarizes the recent CAR-T clinical data that provide an indication as to which subsets of CAR-T cells have the most potential to expand within the patient and therefore provide sustainable remissions. Finally the review discusses alternative CAR immunotherapies by utilizing other cells of the immune system. The review is therefore intended for individuals with a biochemical engineering, biotechnology or similar background who wish to further understand CAR-T immunotherapies from a biological or biotechnological perspective. 


\section{CAR-T cells}

\subsection{CAR design}

Genetically engineered $\mathrm{T}$ cells ectopically expressing CAR are referred to as CAR-T cells. Unlike TCRs, CARs enable highly-specific targeting of antigen in an MHC-independent manner. CARs comprise of extracellular, hinge/transmembrane and intracellular domains (Figure 2). The CAR design has evolved over the years in order to enhance safety and efficacy (Figure 2). First generation CARs were reported by Kuwana and Gross and later by Eshhar et

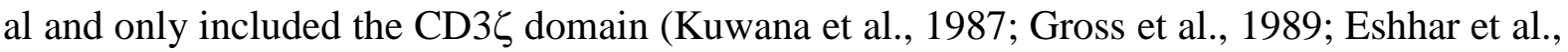
1993), which exhibited minimal response and persistence in vivo (Kershaw et al., 2006; Lamers et al., 2006; Till et al., 2008). Second generation CARs incorporated either CD28 or 4-1BB in addition to $\mathrm{CD} 3 \zeta$ which led to increased efficacy and in vivo persistence (Finney et al., 2004, 1998; Imai et al., 2004; Milone et al., 2009). Third generation CAR constructs have been engineered to contain multiple co-stimulatory domains such as CD28 and 4-1BB in addition to

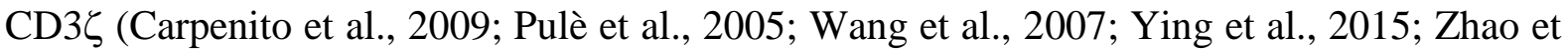
al., 2009) . While some studies suggest that third generation CARs have superior efficacy compared to second generation CARs (Carpenito et al., 2009; Zhong et al., 2010), other studies have shown opposite findings (Abate-Daga et al., 2014; Long et al., 2016). Notably, Kagoya et al increased CAR-T persistence and tumor control in vivo by constructing CAR-T cells containing Signal Transducer and Activator of Transcription 3 and 5 (STAT3/STAT5) activation motifs, thereby mimicking the cytokine-induced signal 3 (Kagoya et al., 2018).

\subsection{How CAR co-stimulatory domains impact the clinical efficacy of CAR-T cells}

As mentioned above, while first generation CARs exhibited limited capacity in vivo, second generation CARs showed greater persistence and tumor killing. Trials conducted with CARs incorporating CD28 or 4-1BB co-stimulatory domains have shown similar initial response rates in patients with ALL (Brentjens et al., 2013; Lee et al., 2015; Maude et al., 2014). However, differences between 4-1BB and CD28 CARs have been reported in patients with chronic lymphoblastic leukemia (CLL) and B-cell lymphoma. 4-1BB CARs appear superior (Maude et al., 2018; Porter et al., 2015; Turtle et al., 2016) by demonstrating persistence for longer than 4 years when compared to CD28 CARs (Kochenderfer et al., 2015; Neelapu et al., 2017) that in some cases exhibited persistence of 30 days (Brentjens et al., 2011; Davila et al., 2014; Lee et al., 2015; Maude et al., 2014).

As a result, efforts are made to understand the fundamental differences in the downstream signaling of 4-1BB and CD28. However, the variability in patient cohorts, clinical trial designs and CAR constructs make it difficult to make robust comparisons. Studies comparing 4-1BB and CD28 CAR-T cells in pre-clinical studies have partially attributed the clinical differences to the distinct metabolic properties that these two domains confer to CAR-T cells. Specifically, while CD28 CAR-T cells exhibited enhanced glycolysis, short-lived effector phenotype and augmented exhaustion phenotype (Chang et al., 2013; Frauwirth et al., 2002; Gubser et al., 2013; Kawalekar et al., 2016; Long et al., 2015), 4-1BB CAR-T cells demonstrated long-term survival, as well as increased mitochondrial biogenesis and oxidative respiration which was ultimately linked to increased frequency of central memory cells (Kawalekar et al., 2016). 
The aforementioned studies indicate that 4-1BB domain is beneficial for CAR-T cell persistence. However, Silva et al showed that tonic (i.e. constitutive signaling with intermediate intensity) 4-1BB signaling can have adverse effects on CAR-T cells (Gomes-Silva et al., 2017). Specifically, tonic 4-1BB signaling resulted in increased CAR-T cell death that was augmented by the use of gamma-retroviral vectors (currently used in $41 \%$ of CAR-T clinical trials [reviewed in (Vormittag et al., 2018)]). These results indicate that 4-1BB may not be universally beneficial for CAR-T cells but rather, the outcome depends on the duration and intensity of the signaling. Finally, in support of the notion that signaling strength is the key determinant of CAR-T cell fate Salter et al carried a phosphoproteomic analysis (an analysis that identifies proteins that have been phosphorylated) in which they identified no major differences in signaling intermediates between 4-1BB and CD28 human CAR-T cells (Salter et al., 2018). Instead, they found that CD28 prompted a more rapid and intense activation of signaling events when compared to 4-1BB CAR-T cells.

Taken together, these studies highlight the importance of in-depth understanding of the signaling events that take place downstream of CAR as they could be key for achieving greater efficacy and persistence of CAR-T cells.

\section{Optimal CAR-T subsets in clinical trials}

An important factor governing CAR-T cell activity in vivo is the subset of T-cell input used. For both murine models and human clinical trials it has been demonstrated that less differentiated $\mathrm{T}$ cell subsets $\left(\mathrm{T}_{\mathrm{CM}}, \mathrm{T}_{\mathrm{SCM}}\right)$ exhibit better persistence, expansion and anti-tumor activity (Gattinoni et al., 2005; Lugli et al., 2013; Crompton et al., 2014). Furthermore, retrospective studies have shown a correlation between increased persistence in vivo and a less differentiated T cell phenotype (Klebanoff et al., 2012; Sommermeyer et al., 2016). Xu et al analysed patients treated with CD19 CAR-T cells and identified a correlation between the level of $\mathrm{T}_{\mathrm{SCM}}$ infused phenotype and in vivo expansion. There is also indication that presence of both $\mathrm{CD}^{+}$and $\mathrm{CD}^{+} \mathrm{T}$ cell subsets results in better anti-tumor responses (Church et al., 2014). Of note, Fraietta et al analysed CAR-T populations isolated from CLL patients that had either responded or not responded to the treatment and identified that CAR-T cells isolated from responders exhibited a gene profile associated with memory formation. In contrast, CAR-T cells isolated from non-responders exhibited a gene profile associated with exhaustion and effector phenotype. Notably, evaluation of $\mathrm{T}$ cell subsets at the point of leukapheresis indicated that responders had a higher frequency of stem-cell like T cells that could be used as predictor of clinical success (Fraietta et al., 2018a). The same group assessed one CLL patient whose disease regressed only after a second CD19 CAR-T infusion (Fraietta et al., 2018b). Analysis of the patient's CAR-T cells at their peak concentration showed that a) all CAR-T cells were derived almost exclusively from a single $\mathrm{T}$ cell clone, $\mathrm{b}$ ) the CAR construct had been unintentionally inserted into one of the two copies of the gene TET2 preventing the gene from producing a functional protein. Further analysis revealed that the patient's T cells had a preexisting mutation in the other copy of TET2, leading to complete lack of functional TET2 protein in the CAR-T cells. TET2-disrupted CAR-T cells exhibited an altered epigenetic profile and at their peak concentration displayed a central memory phenotype, validating the correlation between successful clinical outcome and a less differentiated $T$ cell phenotype. Finally, these results indicate that the progeny of a single CAR-T cell is sufficient to mediate potent anti-tumor effects.

\section{Strategies to improve safety and efficacy of CAR-T cells 4.1. Challenges in CAR-T therapy}


The success of the first CAR-T therapies is unprecedented. However, several challenges remain to be addressed. Patients successfully treated with CD19 CAR-T cells often exhibit profound B cell aplasia (diminished B cell numbers), owing to the fact that CAR-T cells directed against CD19 cannot discriminate between normal and tumor cells (Porter et al., 2011). B cell aplasia has been reported in $15 \%$ and $14-43 \%$ of patients treated with Yescarta and Kymriah respectively (Research, Approved products ).

Similar on-target-off-tumor effects have been observed in CAR-T cells directed against other antigens such as Erb-B2 receptor tyrosine kinase 2 (ERBB2/HER2) and carbonic anhydrase IX (CAIX) where patients deceased due to respective pulmonary failure and hepatotoxicity (Lamers et al., 2013; Morgan et al., 2010). Apart from on-target-off-tumor effects, another commonly observed side effect is cytokine release syndrome (CRS) characterized by high fever, hypoxia, hypotension and/or multi-organ failure. The severity ranges from mild to lifethreatening and is thought to correlate with tumor burden (Brentjens et al., 2013; Lee et al., 2015; Maude et al., 2014; Neelapu et al., 2017). In clinical trials using the CD19 CAR-T products Yescarta and Kymriah, 94\% and $74 \%$ of patients respectively developed CRS (Research, Approved products ). CAR-T-associated neurological toxicities including lifethreatening reactions have also occurred in 58-72\% of patients treated with Kymriah and in $87 \%$ of patients treated with Yescarta (Research, Approved products ). Other challenges associated with CAR-T therapies include resistance to therapy or subsequent relapse due to antigen escape or CAR-T failure (Lee et al., 2015).

In clinical trials directed against B-ALL, disease relapses have been reported in $21-45 \%$ of patients subsequent CD19 CAR-T infusion (Grupp, 2018; Grupp et al., 2013; Lee et al., 2015; Maude et al., 2018, 2016, 2014; Park et al., 2015; Sotillo et al., 2015; Turtle et al., 2016). Multiple mechanisms of tumor escape from therapy have been reported and include downregulation or mutation of CD19, via selection of CD19 negative cells, or via lineage switching (Evans et al., 2015; Gardner et al., 2016; Grupp et al., 2013; Jacoby et al., 2016; Sotillo et al., 2015). Curiously, CD19 epitope loss has not been reported in CLL patients. Resistance to CAR-T therapies in CLL patients appears to be related to the failure of CAR-T cells to expand after infusion (Porter et al., 2015). Furthermore, a recent report of a patient enrolled in Novartis's phase I clinical trial (NCT01626495) testing the safety of their product has highlighted one of the many manufacturing challenges of CAR-T therapies (Ruella et al., 2018). In this case the CAR gene was unintentionally introduced into a single leukemic B cell during $\mathrm{T}$ cell manufacturing. As a result, its product bound to the epitope of CD19 on the surface of the leukemic cell, masking it from recognition and conferring resistance to the CD19 CAR-T treatment, ultimately leading to the death of the patient. Although the report stated that this occurrence was a rare event ( 1 out of 369 enrolled patients), it nevertheless illustrates the need for improved manufacturing technologies for identifying leukemic contaminants at the single cell level.

Finally other challenges, especially in the context of solid tumors, include immunosuppression and limited CAR-T persistence which will be discussed separately below. The severe side effects and relative inefficiencies of the current CAR-T treatments highlight the need for their improvement.

\subsection{Improving safety \& increasing specificity 4.2.1. Suicide genes}


The side effects associated with CAR-T therapies highlight the need for the development of systems that will eliminate these cells if the side effects become life-threatening. Suicide switches such as inducible Caspas9 (iCasp9) and herpes simplex virus thymidine kinase (HSVTK) (Figure 3A, B) allow inducible termination of CAR-T cells some of which are currently being evaluated in clinical trials (NCT03579927, NCT02414269, NCT02107963, NCT01822652). Alternative suicide genes include epitope tags that are recognized by FDAapproved monoclonal antibodies which induce $\mathrm{T}$ cell death via antibody-dependent or complement-dependent cytotoxicity. Examples include Cetuximab targeting a truncated form of the epithelial growth factor receptor (tEGFR) and Rituximab targeting the receptor CD20 (Griffioen et al., 2009; Vogler et al., 2010; Wang et al., 2011; Paszkiewicz et al., 2016; Tasian et al., 2017) (Figure 3C). The compact marker/suicide gene RQR8 that was developed by Philip et al was engineered to combine target epitopes from both CD20 and CD34 (Figure 3C) (Philip et al., 2014). RQR8 is currently tested in clinical trials (NCT03590574, NCT02746952). Additionally, EGFR- mediated CAR-T elimination is currently being tested in clinical trials targeting CD19 (NCT03085173, NCT03618381, NCT02051257, NCT03070327, NCT02028455, NCT02146924, NCT01865617), PD-1 (NCT02937844), EGFR806 (NCT03638167), CD171 (NCT02311621) and CD123 (NCT03114670, NCT02159495).

\subsubsection{Inducible systems}

The irreversible ablation of CAR-T cells may be counterproductive considering that persisting CAR-T cells are necessary to achieve long-lasting clinical success in patients, and that manufacturing of CAR-T cells is both expensive and laborious. Furthermore, the suicide gene in some of the CAR-T cells may not act quickly enough to eliminate the off-tumor toxicity as the death of target cells may take several minutes after induction of the suicide gene. Alternatively, non-cytotoxic, reversible systems may be useful for controlling adverse side effects without ablating the CAR-T population. For example, the CAR construct can be placed under the control of inducible expression systems that can turn the expression of the CAR construct on and off (Sakemura et al., 2016) (Figure 4A). Chemical inducers can also be used to control the assembly of the CAR receptor through drug dimerization domains. In these split receptors the antigen-binding and intracellular signaling domains assemble only in the presence of the dimerizing drug (Wu et al., 2015) (Figure 4B).

\subsubsection{Logic states}

In an effort to decrease the on-target-off-tumor effects as well as reduce tumor escape, strategies using multiple tumor-antigens for full activation of CAR-T cells are currently being developed (synNotch-AND gate; Figure 5A). CARs have also been engineered to discriminate between healthy and malignant tissue by incorporating inhibitory signals (iCARs) that dampen the $T$ cell response when a healthy antigen is present (AND-NOT gate) (Figure 5B). As a result, CAR will be activated only when the cancer-specific antigen is present, and the healthy tissuespecific antigen is absent (Fedorov et al., 2013). Other combinatorial antigen approaches include CARs that can be activated in response to a cell expressing either antigen A or antigen $\mathrm{B}$ (OR gate) (Figure 5C). Others are based on the separation of the domains providing "signal 1 " and "signal 2" necessary for T cell activation (dual CAR) (Figure 5D) that come together only when both antigens are present (Kloss et al., 2013). However reports have shown that activity has been detected in CD3 $\zeta$-only CARs (Pule et al., 2008). Another type of bi-specific CAR has been generated such that the extracellular portion of the CAR construct contains two linked scFvs with different antigen specificities. The CAR-T cells expressing the linked scFvs in tandem (tan CARs) are activated only in the presence of both antigens (Figure 5E) (Grada 
et al., 2013). Tan CARs targeting CD19/CD22, CD19/CD20 and CD38/BCMA are currently being tested in clinical trials for adult and pediatric patients with lymphoma, B-ALL and myeloma (NCT03233854, NCT03241940, NCT03463928, NCT03271515, NCT03767751) (Fry et al., 2018).

Finally, CARs have also been split such that the antigen recognition domain is separated from the signaling motif of the CAR. This configuration uses a universal receptor allowing a large panel of antigens to be targeted without the need to re-engineer immune cells (Urbanska et al., 2012; Rodgers et al., 2016). In an effort to combine many of the aforementioned systems, Cho et al designed a split, universal, and programmable (SUPRA) CAR system that can integrate signals from multiple antigens and fine-tune T cell activation using AND logic gates in a cell type-specific manner (Cho et al., 2018).

\subsection{Sensing tumor microenvironment}

CAR-T cells have also been engineered to apply spatial control and exert their cytotoxic activity only once they reach the tumor tissue (Figure 6A) (Han et al., 2017). A feature of the tumor microenvironment is presence of oxygen in very low levels (hypoxia) (reviewed in (LaGory and Giaccia, 2016)). Consequently, CAR-T cells can be engineered to contain oxygen-sensing domains that degrade in normoxic (normal oxygen) conditions but remain stable in hypoxic conditions (Figure 6B) (Juillerat et al., 2017). Although these features have yet to be tested in human trials and there could be potential off-tumor effects due to certain hypoxic parts of the body, they nevertheless provide a framework for the creation of the next generation, decision-making CAR-T cells.

\subsection{Improving expansion and persistence}

After $\mathrm{T}$ cells home to the site of the tumor, they must undergo rapid expansion. Clinical outcome of CAR-T treatment is correlated with their expansion in vivo (Kalos et al., 2011; Maude et al., 2014; Porter et al., 2015). As discussed, CAR-T cells require signals 1, 2 as well as the cytokine-dependent signal 3 in order to exert potent anti-tumor functions. However, because the tumor microenvironment can be immunosuppressive such activating cytokines are often downregulated (Becker et al., 2013). In order to circumvent this effect, TRUCK CAR-T cells ( $\mathrm{T}$ cells redirected for universal cytokine killing) have been engineered to be armored with activating cytokines (Figure 7A). Pre-clinical studies have shown that delivery of cytokines such as interleukin (IL)-12, IL-15, IL-18 and IL-21 can enhance CAR-T activity and re-shape the tumor micro-environment (Markley and Sadelain, 2010; Chinnasamy et al., 2012; Pegram et al., 2015; Krenciute et al., 2017; Hu et al., 2017; Avanzi et al., 2018). A phase I clinical trial is underway to test the effectiveness of IL-12-secreting CAR-T cells (NCT02498912) (Koneru et al., 2015). Caution must be exerted as exogenous expression of cytokines could counteract the therapeutic effect of CAR-T cells via an indirect induction of immunosuppressive mechanisms (Ahmadzadeh et al., 2009; Spolski et al., 2009). Finally, CAR-Ts can also be loaded with other molecules that can improve expansion or augment $\mathrm{T}$ cell function such as non-coding micro-RNAs that are physiologically involved in T cell regulation (Ohno et al., 2013).

\subsection{Improving anti-immunosuppression}


Immunosuppression is a major challenge for CAR-T therapies, especially in the case of solid tumors as it enables tumor cells to escape from immune responses (Beatty and Moon, 2014). Immune escape is mainly mediated via inhibitory receptors such as programmed cell death-1 (PD-1) and T-lymphocyte associated protein-4 (CTLA-4) and cancer cells often express ligands for these receptors. To overcome this challenge, combined therapies with PD-1 checkpoint inhibitors have been used with CAR-T cells in order to enhance the immune activity of the patient's T cells. Recent clinical reports have suggested that anti-PD-1 agents enhance the efficacy of CD19 CAR-T therapy in patients with DLBCL and ALL(Liu et al., 2016; Maude et al., 2017).

The efficacy of combinatorial PD-1 blockade and CD19 CAR-T is currently being tested in clinical trials (NCT02650999, NCT02926833, NCT02706405). Alternative approaches for disrupting the immunosuppressive pathways are currently being explored and include engineered dominant-negative receptors (NCT00889954) (Foster et al., 2008), "switch" receptors (Liu et al., 2016) and PD-1 monoclonal antibody- expressing CAR-T cells (NCT02873390, NCT02862028) (Suarez et al., 2016). Finally, many groups are in the process of generating CAR-T cells unresponsive to inhibitory signals by knocking-out the genes for PD-1 (NCT03545815), CTLA-4 or lymphocyte activation gene-3 (LAG-3) via the use of CRISPR-Cas9 (clustered regularly-inter- spaced short palindromic repeats-CRISPRassociated system 9) or TALENs (transcription activator-like effector nucleases (Figure 8A) (Menger et al., 2016; Ren et al., 2017; Zhang et al., 2017). Although inhibitory signal blockage may enhance anti-tumor activity of CAR-T cells, it could also increase toxicity owing to the reduction of $\mathrm{T}$ cell safety mechanisms which could ultimately result to uncontrolled activity of T cells. Notably, although CRISPR/Cas9 technology has been successfully applied to engineer $\mathrm{T}$ cells, a major issue with the system is that it is bacterially derived and therefore may be sufficiently immunogenic to interfere the delivery of CRISPR/Cas9- edited $\mathrm{T}$ cells (Charlesworth et al., 2018; Wagner et al., 2018). Furthermore, studies have indicated that cells amendable via CRISPR/Cas9 engineering may also be more susceptible to malignant transformation (Haapaniemi et al., 2018; Ihry et al., 2018).

\subsection{Tumor stroma and homing}

Advances have been made to tackle other issues regarding CAR-T efficacy in solid tumors. Such advances include directly modulating cells that surround the tumor in order to make it easier for CAR-T cells to infiltrate the periphery (Figure 8B) (Perera et al., 2017; Ruella et al., 2017), and to improve homing of CAR-T cells to the tumor by expressing chemokine receptors which will bind to tumor ligands (Figure 7B) (Di Stasi et al., 2009; Craddock et al., 2010; Moon et al., 2011; Siddiqui et al., 2016). Many of these emerging innovations remain to show feasibility and effectiveness in human clinical trials.

\section{Alternative CAR immunotherapies}

As the field of immunotherapies continues to develop, alternative avenues are currently being explored. Notable examples include a distinct and less common type of T cells, gamma delta $\mathrm{T}$ cells $(\gamma \delta \mathrm{T})$. Unlike conventional T cells that are currently used for CAR-T therapies and express $\alpha \beta$ TCR, $\gamma \delta$ T cells express $\gamma \delta$ TCR. Furthermore, while conventional T cells rely on specific antigens for target recognition, $\gamma \delta \mathrm{T}$ cells recognize "stress-antigens" which are indicative of malignant transformation or infection (Groh et al., 2002, 1998; Rincon-Orozco et al., 2005; Wrobel et al., 2007). This feature provides a distinct advantage in the context of 
cancer therapy since they can recognize several types of cancer cells. Given that $\gamma \delta \mathrm{T}$ recognition does not depend on MHC presentation, these cells make an ideal candidate for allogeneic "off-the-shelf" therapies. TC Biopharm is currently in a phase II clinical trial utilizing autologous, genetically unmodified $\gamma \delta \mathrm{T}$ cells for the treatment of refractory malignant melanoma, renal cell cancer and non-small cell lung cancer (NCT02459067). Similarly, Incysus is expected to initiate a phase I clinical trial utilizing allogeneic (but haplo-identical), genetically unmodified $\gamma \delta$ T cells (NCT03533816). Gadeta recently partnered up with Kite Pharma/Gilead to bring their innovative technology into clinical trials. Gadeta genetically engineers conventional $\alpha \beta$ T cells to express $\gamma \delta$ TCR thereby combining the advantages of both T cell sub-types. Clinical trials are expected to initiate soon. Finally, a spin-out of King's College London GammaDelta Therapeutics, is also entering the space by focusing on a specific sub-type of $\gamma \delta$ T cell. While $\alpha \beta$ T-based cell immunotherapies have shown limited capacity against solid tumors, $\gamma \delta \mathrm{T}$ cells have shown promise. Data from clinical trials remain to demonstrate whether $\gamma \delta \mathrm{T}$ cells are efficacious as an immunotherapy against solid and other tumors.

It is generally accepted that the tumor microenvironment can have immunosuppressive effects (Buckanovich et al., 2008; Spranger et al., 2015). Therefore immune cells that are more resilient against these effects should exert superior tumor-killing capacity within the immunosuppressive tumor microenvironment. Macrophages represent an attractive candidate as an immunotherapy against solid tumors. Myeloid cells such as macrophages are actively recruited to tumor sites to perform various anti- and pro-tumor functions (Jaiswal et al., 2009; Lee et al., 2013; Oosterling et al., 2005). As part of the innate immune system, macrophages directly kill target cells via phagocytosis. Furthermore, given that macrophages are professional APCs, they can elicit an adaptive immune response by directing $\mathrm{T}$ cells against tumor cells. Carisma Therapeutics, a spin-out of University of Pennsylvania, focuses on the development of macrophage-based immunotherapies and is the first technology to combine antigen recognition with the effector function of macrophages. Clinical development is anticipated to initiate in 2019. Similarly, MaxCyte is in the process of testing an autologous CARMacrophage (MCY-M11) product in a phase I clinical (NCT03608618).

NK cells are part of the innate immune system and as opposed to T cells, have the inherent ability to kill malignant cells without prior sensitization, therefore playing a key role in tumor imunosurveillance (Herberman et al., 1975; Kärre et al., 1986; Kiessling et al., 1975; Ljunggren and Kärre, 1985; Ruggeri et al., 2006, 2002). NK cells exert their cytotoxic effects based on a tight regulation of activating and inhibitory receptors found on their surface (Malmberg et al., 2017). Physiologically nearly all healthy cells express class I MHC molecules, which bind to the inhibitory receptors on the surface of NK cells and inhibit their killing capabilities. However, malignant cells often undergo surface marker changes such as loss/downregulation of their class I MHC and upregulation of damage-associated stress antigens. As a result, NK cells can kill tumor cells through these two pathways. On the one hand absence of class I MHC results in loss of inhibitory signals causing the activation of NK cells (Ljunggren and Kärre, 1990). On the other hand damage-associated signals on the surface of tumor cells bind to the activating receptors on NK cells thus triggering the cytotoxicity of NK cells which can target cell death both directly and indirectly. Finally, similarly to $\gamma \delta \mathrm{T}$ cells, NK cells do not require MHC recognition thus making them ideal for an "off-the-shelf" therapy. Clinical trials using NK-based immunotherapies have been initiated for blood malignancies (NCT03056339, NCT01974479, NCT02944162, NCT02742727, NCT02892695, NCT00995137) as well as for metastatic solid tumors (NCT03415100, NCT02839954). These trials have used NKs derived 
from various sources such as peripheral blood for autologous therapies or peripheral blood, umbilical cord blood and NK cell-line NK-92 for allogeneic therapies.

On the allogeneic off-the-shelf front, clinical trials in phase I led by Cellectis are testing the clinical efficacy and safety of their genetically modified allogeneic CAR-T products UCART19 (NCT02735083) and UCART123 (NCT03190278) for hematological malignancies. More of their allogeneic CAR-T products such as UCART22, UCARTCS1 and UCART38 are also underway to clinical trials. Celyad who has autologous CAR-T products currently tested in phase I clinical trials (NCT03018405, NCT03612739), has recently received approval to initiate clinical trials using allogeneic CAR-T cells in patients with colorectal cancer (NCT03692429).

Finally, Fate therapeutics has generated induced pluripotent stem cell (iPSCs) master cell banks to subsequently generate iPSC-derived CAR-T or CAR-NK cells providing provide off-theshelf immunotherapies. Notable examples include the allogeneic CAR-T FT819 defined by the integration of CD19 CAR into the $\mathrm{T}$ cell receptor alpha locus (TRAC) providing both antigen specificity while eliminating the potential of graft-versus-host disease (GvHD) mediated via the lack of TCR, and the expression of a non-cleavable form of CD16 to address tumor antigen escape. CD16 mediates activation of NK cells by binding to the Fc portion of monoclonal antibodies thereby mediating antibody-dependent cellular cytotoxicity (ADCC). As a result, NK recognition of an antibody-coated target cell results in rapid NK activation and lysis of the target cell. In the presence of monoclonal antibodies targeting tumor cells, ADCC can be activated as an additional mechanism to target them. FT519 is another allogeneic CAR-NK product that in addition to the aforementioned features contains the additional modality of IL15 expression to provide self-stimulating signals for enhanced NK function and persistence. The results of these pre-clinical studies demonstrated that iPSC-derived, off-the-shelf immunotherapies could be used effectively for the treatment of malignancies in an allogeneic setting (Clarke, 2018; Kaufman, 2018). These products remain to be tested in human clinical trials.

\section{Concluding remarks and future outlook}

In the past year, the CD19 CAR-T products Kymriah and Yescarta have gained approval by the European Medicines Agency (EMA) for their use in the European Union following their approval by the FDA. While Kymriah was granted approval by the UK's National Institute for Healthcare and Excellence (NICE) for its use to treat children and adults up to 25 years suffering from B-ALL, it was turned down for its use in adults suffering from DLBCL, a disease affecting more than 4,800 people in the UK (https://lymphoma-action.org.uk). This decision was largely based on the drug's listed price of $£ 282,000$. Similarly, NICE initially turned down Gilead's Yescarta for the treatment of adult DLBCL patients but eventually reached a deal after agreeing on a confidential discount on its listed price of $£ 300,000$. The significant costs associated with personalized cell and gene therapies, at present, represents a critical barrier to adoption. However, as the emerging scientific breakthroughs in recent years (e.g. genome editing) are integrated into process development, manufacturing platforms and technologies can be optimized to reduce costs whilst maintaining clinical efficacy. Moreover, with the emergence of allogeneic CAR-T therapies currently entering Phase 1 clinical trials and significant investment in such approaches, this is likely to significantly reduce the cost of manufacture through economies of scale, presenting a different manufacturing paradigm and business model to autologous CAR-T production. However, the safety and efficacy of an offthe-shelf CAR-T therapy is yet to be proven and technical challenges associated with sourcing 
appropriate donors and preservation of incoming starting material and outgoing final product necessary to uncouple the logistics from the manufacturing process must be overcome.

Currently CAR-T treatments are available for a very small proportion of cancer patients as ALL incidence in the UK represents less than $1 \%$ of all cancers, corresponding to 800 patients (https://www.cancerresearchuk.org). The issue of high cost will become exacerbated if and when CAR-T treatments either become available for larger patient cohorts such as those suffering from breast and prostate cancer, which are the first and second most common cancers in the UK (15\% and $13 \%$ respectively corresponding to 55,000 and 47,000 patients) (https://www.cancerresearchuk.org), or if CAR-T therapies are utilized as a first-line treatment. Aside from the manufacturing challenges, addressing the challenges surrounding resistance to treatment, disease relapse, severe side effects and limited persistence, will require a holistic understanding of the biological complexity of these immunotherapies. Importantly, the clinical trials used to bring these products to market comprise of small patient cohorts and are inherently difficult to compare due to differences in trial design. Clinical trials implementing a direct comparison between the approved products would offer tremendous insight.

Finally, although CAR-T therapies are transforming the management of hematological malignancies there are several hurdles that remain to be overcome in order to successfully utilize immunotherapies for solid tumors.

\section{Acknowledgements}

The authors would like to acknowledge the EPSRC for funding this work through the "New Industrial Systems: Optimising Me Manufacturing Systems", Grant Number EP/R022534/1 and "Future Targeted Healthcare Manufacturing Hub", Grant Number EP/P006485/1. 


\section{References}

Abate-Daga, D., Lagisetty, K.H., Tran, E., Zheng, Z., Gattinoni, L., Yu, Z., Burns, W.R., Miermont, A.M., Teper, Y., Rudloff, U., Restifo, N.P., Feldman, S.A., Rosenberg, S.A., Morgan, R.A., 2014. A novel chimeric antigen receptor against prostate stem cell antigen mediates tumor destruction in a humanized mouse model of pancreatic cancer. Hum. Gene Ther. 25, 1003-1012. https://doi.org/10.1089/hum.2013.209

Ahmadzadeh, M., Johnson, L.A., Heemskerk, B., Wunderlich, J.R., Dudley, M.E., White, D.E., Rosenberg, S.A., 2009. Tumor antigen-specific CD8 T cells infiltrating the tumor express high levels of PD-1 and are functionally impaired. Blood 114, 1537-1544. https://doi.org/10.1182/blood-2008-12-195792

Avanzi, M.P., Yeku, O., Li, X., Wijewarnasuriya, D.P., van Leeuwen, D.G., Cheung, K., Park, H., Purdon, T.J., Daniyan, A.F., Spitzer, M.H., Brentjens, R.J., 2018. Engineered Tumor-Targeted T Cells Mediate Enhanced Anti-Tumor Efficacy Both Directly and through Activation of the Endogenous Immune System. Cell Rep. 23, 2130-2141. https://doi.org/10.1016/j.celrep.2018.04.051

Beatty, G.L., Moon, E.K., 2014. Chimeric antigen receptor T cells are vulnerable to immunosuppressive mechanisms present within the tumor microenvironment. Oncoimmunology 3, e970027. https://doi.org/10.4161/21624011.2014.970027

Becker, J.C., Andersen, M.H., Schrama, D., Thor Straten, P., 2013. Immune-suppressive properties of the tumor microenvironment. Cancer Immunol. Immunother. CII 62, 1137-1148. https://doi.org/10.1007/s00262-013-1434-6

Brentjens, R.J., Davila, M.L., Riviere, I., Park, J., Wang, X., Cowell, L.G., Bartido, S., Stefanski, J., Taylor, C., Olszewska, M., Borquez-Ojeda, O., Qu, J., Wasielewska, T., He, Q., Bernal, Y., Rijo, I.V., Hedvat, C., Kobos, R., Curran, K., Steinherz, P., Jurcic, J., Rosenblat, T., Maslak, P., Frattini, M., Sadelain, M., 2013. CD19-targeted T cells rapidly induce molecular remissions in adults with chemotherapy-refractory acute lymphoblastic leukemia. Sci. Transl. Med. 5, 177 ra38. https://doi.org/10.1126/scitranslmed.3005930

Brentjens, R.J., Rivière, I., Park, J.H., Davila, M.L., Wang, X., Stefanski, J., Taylor, C., Yeh, R., Bartido, S., Borquez-Ojeda, O., Olszewska, M., Bernal, Y., Pegram, H., Przybylowski, M., Hollyman, D., Usachenko, Y., Pirraglia, D., Hosey, J., Santos, E., Halton, E., Maslak, P., Scheinberg, D., Jurcic, J., Heaney, M., Heller, G., Frattini, M., Sadelain, M., 2011. Safety and persistence of adoptively transferred autologous CD19targeted $\mathrm{T}$ cells in patients with relapsed or chemotherapy refractory B-cell leukemias. Blood 118, 4817-4828. https://doi.org/10.1182/blood-2011-04-348540

Buckanovich, R.J., Facciabene, A., Kim, S., Benencia, F., Sasaroli, D., Balint, K., Katsaros, D., O’Brien-Jenkins, A., Gimotty, P.A., Coukos, G., 2008. Endothelin B receptor mediates the endothelial barrier to $\mathrm{T}$ cell homing to tumors and disables immune therapy. Nat. Med. 14, 28-36. https://doi.org/10.1038/nm1699

Carpenito, C., Milone, M.C., Hassan, R., Simonet, J.C., Lakhal, M., Suhoski, M.M., VarelaRohena, A., Haines, K.M., Heitjan, D.F., Albelda, S.M., Carroll, R.G., Riley, J.L., Pastan, I., June, C.H., 2009. Control of large, established tumor xenografts with genetically retargeted human T cells containing CD28 and CD137 domains. Proc. Natl. Acad. Sci. U. S. A. 106, 3360-3365. https://doi.org/10.1073/pnas.0813101106

Chang, C.-H., Curtis, J.D., Maggi, L.B., Faubert, B., Villarino, A.V., O’Sullivan, D., Huang, S.C.-C., van der Windt, G.J.W., Blagih, J., Qiu, J., Weber, J.D., Pearce, E.J., Jones, 
R.G., Pearce, E.L., 2013. Posttranscriptional control of T cell effector function by aerobic glycolysis. Cell 153, 1239-1251. https://doi.org/10.1016/j.cell.2013.05.016

Charlesworth, C.T., Deshpande, P.S., Dever, D.P., Dejene, B., Gomez-Ospina, N., Mantri, S., Pavel-Dinu, M., Camarena, J., Weinberg, K.I., Porteus, M.H., 2018. Identification of Pre-Existing Adaptive Immunity to Cas9 Proteins in Humans. https://doi.org/10.1101/243345

Chinnasamy, D., Yu, Z., Kerkar, S.P., Zhang, L., Morgan, R.A., Restifo, N.P., Rosenberg, S.A., 2012. Local delivery of interleukin-12 using $T$ cells targeting VEGF receptor-2 eradicates multiple vascularized tumors in mice. Clin. Cancer Res. Off. J. Am. Assoc. Cancer Res. 18, 1672-1683. https://doi.org/10.1158/1078-0432.CCR-11-3050

Cho, J.H., Collins, J.J., Wong, W.W., 2018. Universal Chimeric Antigen Receptors for Multiplexed and Logical Control of T Cell Responses. Cell 173, 1426-1438.e11. https://doi.org/10.1016/j.cell.2018.03.038

Church, S.E., Jensen, S.M., Antony, P.A., Restifo, N.P., Fox, B.A., 2014. Tumor-specific CD4+ $\mathrm{T}$ cells maintain effector and memory tumor-specific CD8+ $\mathrm{T}$ cells. Eur. J. Immunol. 44, 69-79. https://doi.org/10.1002/eji.201343718

Clarke, R., 2018. Pluripotent Cell-Derived Off-the-Shelf TCR-Less CAR-Targeted Cytotoxic T Cell Therapeutic for the Allogeneic Treatment of B Cell Malignancies. Presented at the 60th Annual Meeting and Exposition (December 1-4, 2018), ASH.

Craddock, J.A., Lu, A., Bear, A., Pule, M., Brenner, M.K., Rooney, C.M., Foster, A.E., 2010. Enhanced tumor trafficking of GD2 chimeric antigen receptor T cells by expression of the chemokine receptor CCR2b. J. Immunother. Hagerstown Md 1997 33, 780-788. https://doi.org/10.1097/CJI.0b013e3181ee6675

Crompton, J.G., Sukumar, M., Restifo, N.P., 2014. Uncoupling T-cell expansion from effector differentiation in cell-based immunotherapy. Immunol. Rev. 257, 264-276. https://doi.org/10.1111/imr.12135

Davila, M.L., Riviere, I., Wang, X., Bartido, S., Park, J., Curran, K., Chung, S.S., Stefanski, J., Borquez-Ojeda, O., Olszewska, M., Qu, J., Wasielewska, T., He, Q., Fink, M., Shinglot, H., Youssif, M., Satter, M., Wang, Y., Hosey, J., Quintanilla, H., Halton, E., Bernal, Y., Bouhassira, D.C.G., Arcila, M.E., Gonen, M., Roboz, G.J., Maslak, P., Douer, D., Frattini, M.G., Giralt, S., Sadelain, M., Brentjens, R., 2014. Efficacy and toxicity management of 19-28z CAR T cell therapy in B cell acute lymphoblastic leukemia. Sci. Transl. Med. 6, 224ra25. https://doi.org/10.1126/scitranslmed.3008226

Di Stasi, A., De Angelis, B., Rooney, C.M., Zhang, L., Mahendravada, A., Foster, A.E., Heslop, H.E., Brenner, M.K., Dotti, G., Savoldo, B., 2009. T lymphocytes coexpressing CCR4 and a chimeric antigen receptor targeting CD30 have improved homing and antitumor activity in a Hodgkin tumor model. Blood 113, 6392-6402. https://doi.org/10.1182/blood-2009-03-209650

Eshhar, Z., Waks, T., Gross, G., Schindler, D.G., 1993. Specific activation and targeting of cytotoxic lymphocytes through chimeric single chains consisting of antibody-binding domains and the gamma or zeta subunits of the immunoglobulin and T-cell receptors. Proc. Natl. Acad. Sci. U. S. A. 90, 720-724.

Evans, A.G., Rothberg, P.G., Burack, W.R., Huntington, S.F., Porter, D.L., Friedberg, J.W., Liesveld, J.L., 2015. Evolution to plasmablastic lymphoma evades CD19-directed chimeric antigen receptor $\mathrm{T}$ cells. Br. J. Haematol. 171, 205-209. https://doi.org/10.1111/bjh.13562

Fedorov, V.D., Themeli, M., Sadelain, M., 2013. PD-1- and CTLA-4-based inhibitory chimeric antigen receptors (iCARs) divert off-target immunotherapy responses. Sci. Transl. Med. 5, 215ra172. https://doi.org/10.1126/scitranslmed.3006597 
Finney, H.M., Akbar, A.N., Lawson, A.D.G., 2004. Activation of resting human primary T cells with chimeric receptors: costimulation from CD28, inducible costimulator, CD134, and CD137 in series with signals from the TCR zeta chain. J. Immunol. Baltim. Md 1950 172, 104-113.

Finney, H.M., Lawson, A.D., Bebbington, C.R., Weir, A.N., 1998. Chimeric receptors providing both primary and costimulatory signaling in $\mathrm{T}$ cells from a single gene product. J. Immunol. Baltim. Md 1950 161, 2791-2797.

Foster, A.E., Dotti, G., Lu, A., Khalil, M., Brenner, M.K., Heslop, H.E., Rooney, C.M., Bollard, C.M., 2008. Antitumor activity of EBV-specific T lymphocytes transduced with a dominant negative TGF-beta receptor. J. Immunother. Hagerstown Md 1997 31, 500-505. https://doi.org/10.1097/CJI.0b013e318177092b

Fraietta, J.A., Lacey, S.F., Orlando, E.J., Pruteanu-Malinici, I., Gohil, M., Lundh, S., Boesteanu, A.C., Wang, Y., O'Connor, R.S., Hwang, W.-T., Pequignot, E., Ambrose, D.E., Zhang, C., Wilcox, N., Bedoya, F., Dorfmeier, C., Chen, F., Tian, L., Parakandi, H., Gupta, M., Young, R.M., Johnson, F.B., Kulikovskaya, I., Liu, L., Xu, J., Kassim, S.H., Davis, M.M., Levine, B.L., Frey, N.V., Siegel, D.L., Huang, A.C., Wherry, E.J., Bitter, H., Brogdon, J.L., Porter, D.L., June, C.H., Melenhorst, J.J., 2018a. Determinants of response and resistance to CD19 chimeric antigen receptor (CAR) T cell therapy of chronic lymphocytic leukemia. Nat. Med. 24, 563-571. https://doi.org/10.1038/s41591-018-0010-1

Fraietta, J.A., Nobles, C.L., Sammons, M.A., Lundh, S., Carty, S.A., Reich, T.J., Cogdill, A.P., Morrissette, J.J.D., DeNizio, J.E., Reddy, S., Hwang, Y., Gohil, M., Kulikovskaya, I., Nazimuddin, F., Gupta, M., Chen, F., Everett, J.K., Alexander, K.A., Lin-Shiao, E., Gee, M.H., Liu, X., Young, R.M., Ambrose, D., Wang, Y., Xu, J., Jordan, M.S., Marcucci, K.T., Levine, B.L., Garcia, K.C., Zhao, Y., Kalos, M., Porter, D.L., Kohli, R.M., Lacey, S.F., Berger, S.L., Bushman, F.D., June, C.H., Melenhorst, J.J., 2018b. Disruption of TET2 promotes the therapeutic efficacy of CD19-targeted T cells. Nature 558, 307-312. https://doi.org/10.1038/s41586-018-0178-z

Frauwirth, K.A., Riley, J.L., Harris, M.H., Parry, R.V., Rathmell, J.C., Plas, D.R., Elstrom, R.L., June, C.H., Thompson, C.B., 2002. The CD28 signaling pathway regulates glucose metabolism. Immunity 16, 769-777.

Fry, T.J., Shah, N.N., Orentas, R.J., Stetler-Stevenson, M., Yuan, C.M., Ramakrishna, S., Wolters, P., Martin, S., Delbrook, C., Yates, B., Shalabi, H., Fountaine, T.J., Shern, J.F., Majzner, R.G., Stroncek, D.F., Sabatino, M., Feng, Y., Dimitrov, D.S., Zhang, L., Nguyen, S., Qin, H., Dropulic, B., Lee, D.W., Mackall, C.L., 2018. CD22-targeted CAR T cells induce remission in B-ALL that is naive or resistant to CD19-targeted CAR immunotherapy. Nat. Med. 24, 20-28. https://doi.org/10.1038/nm.4441

Gardner, R., Wu, D., Cherian, S., Fang, M., Hanafi, L.-A., Finney, O., Smithers, H., Jensen, M.C., Riddell, S.R., Maloney, D.G., Turtle, C.J., 2016. Acquisition of a CD19-negative myeloid phenotype allows immune escape of MLL-rearranged B-ALL from CD19 CAR-T-cell therapy. Blood 127, 2406-2410. https://doi.org/10.1182/blood-2015-08665547

Gattinoni, L., Klebanoff, C.A., Palmer, D.C., Wrzesinski, C., Kerstann, K., Yu, Z., Finkelstein, S.E., Theoret, M.R., Rosenberg, S.A., Restifo, N.P., 2005. Acquisition of full effector function in vitro paradoxically impairs the in vivo antitumor efficacy of adoptively transferred CD8+ $\mathrm{T}$ cells. J. Clin. Invest. 115, 1616-1626. https://doi.org/10.1172/JCI24480

Gattinoni, L., Lugli, E., Ji, Y., Pos, Z., Paulos, C.M., Quigley, M.F., Almeida, J.R., Gostick, E., Yu, Z., Carpenito, C., Wang, E., Douek, D.C., Price, D.A., June, C.H., Marincola, 
F.M., Roederer, M., Restifo, N.P., 2011. A human memory T cell subset with stem celllike properties. Nat. Med. 17, 1290-1297. https://doi.org/10.1038/nm.2446

Gattinoni, L., Zhong, X.-S., Palmer, D.C., Ji, Y., Hinrichs, C.S., Yu, Z., Wrzesinski, C., Boni, A., Cassard, L., Garvin, L.M., Paulos, C.M., Muranski, P., Restifo, N.P., 2009. Wnt signaling arrests effector $\mathrm{T}$ cell differentiation and generates CD8+ memory stem cells. Nat. Med. 15, 808-813. https://doi.org/10.1038/nm.1982

Gebhardt, T., Wakim, L.M., Eidsmo, L., Reading, P.C., Heath, W.R., Carbone, F.R., 2009. Memory $\mathrm{T}$ cells in nonlymphoid tissue that provide enhanced local immunity during infection with herpes simplex virus. Nat. Immunol. 10, 524-530. https://doi.org/10.1038/ni.1718

Gomes-Silva, D., Mukherjee, M., Srinivasan, M., Krenciute, G., Dakhova, O., Zheng, Y., Cabral, J.M.S., Rooney, C.M., Orange, J.S., Brenner, M.K., Mamonkin, M., 2017. Tonic 4-1BB Costimulation in Chimeric Antigen Receptors Impedes T Cell Survival and Is Vector-Dependent. Cell Rep. 21, 17-26. https://doi.org/10.1016/j.celrep.2017.09.015

Grada, Z., Hegde, M., Byrd, T., Shaffer, D.R., Ghazi, A., Brawley, V.S., Corder, A., Schönfeld, K., Koch, J., Dotti, G., Heslop, H.E., Gottschalk, S., Wels, W.S., Baker, M.L., Ahmed, N., 2013. TanCAR: A Novel Bispecific Chimeric Antigen Receptor for Cancer Immunotherapy. Mol. Ther. Nucleic Acids 2, e105. https://doi.org/10.1038/mtna.2013.32

Griffioen, M., van Egmond, E.H.M., Kester, M.G.D., Willemze, R., Falkenburg, J.H.F., Heemskerk, M.H.M., 2009. Retroviral transfer of human CD20 as a suicide gene for adoptive T-cell therapy. Haematologica 94, 1316-1320. https://doi.org/10.3324/haematol.2008.001677

Groh, V., Steinle, A., Bauer, S., Spies, T., 1998. Recognition of stress-induced MHC molecules by intestinal epithelial gammadelta T cells. Science 279, 1737-1740.

Groh, V., Wu, J., Yee, C., Spies, T., 2002. Tumour-derived soluble MIC ligands impair expression of NKG2D and T-cell activation. Nature 419, 734-738. https://doi.org/10.1038/nature01112

Gross, G., Waks, T., Eshhar, Z., 1989. Expression of immunoglobulin-T-cell receptor chimeric molecules as functional receptors with antibody-type specificity. Proc. Natl. Acad. Sci. U. S. A. 86, 10024-10028.

Grupp, S., 2018. Updated Analysis of the Efficacy and Safety of Tisagenlecleucel in Pediatric and Young Adult Patients with Relapsed/Refractory ( $\mathrm{r} / \mathrm{r}$ ) Acute Lymphoblastic Leukemia. Presented at the 60th Annual Meeting and Exposition (December 1-4, 2018), ASH.

Grupp, S.A., Kalos, M., Barrett, D., Aplenc, R., Porter, D.L., Rheingold, S.R., Teachey, D.T., Chew, A., Hauck, B., Wright, J.F., Milone, M.C., Levine, B.L., June, C.H., 2013. Chimeric antigen receptor-modified T cells for acute lymphoid leukemia. N. Engl. J. Med. 368, 1509-1518. https://doi.org/10.1056/NEJMoa1215134

Gubser, P.M., Bantug, G.R., Razik, L., Fischer, M., Dimeloe, S., Hoenger, G., Durovic, B., Jauch, A., Hess, C., 2013. Rapid effector function of memory CD8+ T cells requires an immediate-early glycolytic switch. Nat. Immunol. 14, 1064-1072. https://doi.org/10.1038/ni.2687

Haapaniemi, E., Botla, S., Persson, J., Schmierer, B., Taipale, J., 2018. CRISPR-Cas9 genome editing induces a p53-mediated DNA damage response. Nat. Med. 24, 927. https://doi.org/10.1038/s41591-018-0049-z

Han, X., Bryson, P.D., Zhao, Y., Cinay, G.E., Li, S., Guo, Y., Siriwon, N., Wang, P., 2017. Masked Chimeric Antigen Receptor for Tumor-Specific Activation. Mol. Ther. J. Am. Soc. Gene Ther. 25, 274-284. https://doi.org/10.1016/j.ymthe.2016.10.011 
Herberman, R.B., Nunn, M.E., Lavrin, D.H., 1975. Natural cytotoxic reactivity of mouse lymphoid cells against syngeneic acid allogeneic tumors. I. Distribution of reactivity and specificity. Int. J. Cancer 16, 216-229.

Hofmann, M., Pircher, H., 2011. E-cadherin promotes accumulation of a unique memory CD8 T-cell population in murine salivary glands. Proc. Natl. Acad. Sci. U. S. A. 108, 1674116746. https://doi.org/10.1073/pnas.1107200108

Hu, B., Ren, J., Luo, Y., Keith, B., Young, R.M., Scholler, J., Zhao, Y., June, C.H., 2017. Augmentation of Antitumor Immunity by Human and Mouse CAR T Cells Secreting IL-18. Cell Rep. 20, 3025-3033. https://doi.org/10.1016/j.celrep.2017.09.002

Ihry, R.J., Worringer, K.A., Salick, M.R., Frias, E., Ho, D., Theriault, K., Kommineni, S., Chen, J., Sondey, M., Ye, C., Randhawa, R., Kulkarni, T., Yang, Z., McAllister, G., Russ, C., Reece-Hoyes, J., Forrester, W., Hoffman, G.R., Dolmetsch, R., Kaykas, A., 2018. p53 inhibits CRISPR-Cas9 engineering in human pluripotent stem cells. Nat. Med. 24, 939. https://doi.org/10.1038/s41591-018-0050-6

Imai, C., Mihara, K., Andreansky, M., Nicholson, I.C., Pui, C.-H., Geiger, T.L., Campana, D., 2004. Chimeric receptors with 4-1BB signaling capacity provoke potent cytotoxicity against acute lymphoblastic leukemia. Leukemia 18, 676-684. https://doi.org/10.1038/sj.leu.2403302

Jacoby, E., Nguyen, S.M., Fountaine, T.J., Welp, K., Gryder, B., Qin, H., Yang, Y., Chien, C.D., Seif, A.E., Lei, H., Song, Y.K., Khan, J., Lee, D.W., Mackall, C.L., Gardner, R.A., Jensen, M.C., Shern, J.F., Fry, T.J., 2016. CD19 CAR immune pressure induces B-precursor acute lymphoblastic leukaemia lineage switch exposing inherent leukaemic plasticity. Nat. Commun. 7, 12320. https://doi.org/10.1038/ncomms12320

Jaiswal, S., Jamieson, C.H.M., Pang, W.W., Park, C.Y., Chao, M.P., Majeti, R., Traver, D., van Rooijen, N., Weissman, I.L., 2009. CD47 is upregulated on circulating hematopoietic stem cells and leukemia cells to avoid phagocytosis. Cell 138, 271-285. https://doi.org/10.1016/j.cell.2009.05.046

Juillerat, A., Marechal, A., Filhol, J.M., Valogne, Y., Valton, J., Duclert, A., Duchateau, P., Poirot, L., 2017. An oxygen sensitive self-decision making engineered CAR T-cell. Sci. Rep. 7. https://doi.org/10.1038/srep39833

Kagoya, Y., Tanaka, S., Guo, T., Anczurowski, M., Wang, C.-H., Saso, K., Butler, M.O., Minden, M.D., Hirano, N., 2018. A novel chimeric antigen receptor containing a JAKSTAT signaling domain mediates superior antitumor effects. Nat. Med. 24, 352-359. https://doi.org/10.1038/nm.4478

Kalos, M., Levine, B.L., Porter, D.L., Katz, S., Grupp, S.A., Bagg, A., June, C.H., 2011. T cells with chimeric antigen receptors have potent antitumor effects and can establish memory in patients with advanced leukemia. Sci. Transl. Med. 3, 95ra73. https://doi.org/10.1126/scitranslmed.3002842

Kärre, K., Ljunggren, H.G., Piontek, G., Kiessling, R., 1986. Selective rejection of H-2deficient lymphoma variants suggests alternative immune defence strategy. Nature 319, 675-678. https://doi.org/10.1038/319675a0

Kaufman, D., 2018. Off-the-Shelf Natural Killer Cells with Multi-Functional Engineering Using a Novel Anti-CD19 Chimeric Antigen Receptor Combined with Stabilized CD16 and IL15 Expression to Enhance Directed Anti-Tumor Activity. Presented at the 60th Annual Meeting and Exposition (December 1-4, 2018), ASH.

Kawalekar, O.U., O’Connor, R.S., Fraietta, J.A., Guo, L., McGettigan, S.E., Posey, A.D., Patel, P.R., Guedan, S., Scholler, J., Keith, B., Snyder, N.W., Snyder, N., Blair, I.A., Blair, I., Milone, M.C., June, C.H., 2016. Distinct Signaling of Coreceptors Regulates Specific Metabolism Pathways and Impacts Memory Development in CAR T Cells. Immunity 44, 380-390. https://doi.org/10.1016/j.immuni.2016.01.021 
Kershaw, M.H., Westwood, J.A., Parker, L.L., Wang, G., Eshhar, Z., Mavroukakis, S.A., White, D.E., Wunderlich, J.R., Canevari, S., Rogers-Freezer, L., Chen, C.C., Yang, J.C., Rosenberg, S.A., Hwu, P., 2006. A phase I study on adoptive immunotherapy using gene-modified T cells for ovarian cancer. Clin. Cancer Res. Off. J. Am. Assoc. Cancer Res. 12, 6106-6115. https://doi.org/10.1158/1078-0432.CCR-06-1183

Kiessling, R., Klein, E., Wigzell, H., 1975. "Natural" killer cells in the mouse. I. Cytotoxic cells with specificity for mouse Moloney leukemia cells. Specificity and distribution according to genotype. Eur. J. Immunol. 5, 112-117. https://doi.org/10.1002/eji.1830050208

Klebanoff, C.A., Gattinoni, L., Restifo, N.P., 2012. Sorting through subsets: which T-cell populations mediate highly effective adoptive immunotherapy? J. Immunother. Hagerstown Md 1997 35, 651-660. https://doi.org/10.1097/CJI.0b013e31827806e6

Kloss, C.C., Condomines, M., Cartellieri, M., Bachmann, M., Sadelain, M., 2013. Combinatorial antigen recognition with balanced signaling promotes selective tumor eradication by engineered $\mathrm{T}$ cells. Nat. Biotechnol. 31, 71-75. https://doi.org/10.1038/nbt.2459

Kochenderfer, J.N., Dudley, M.E., Kassim, S.H., Somerville, R.P.T., Carpenter, R.O., StetlerStevenson, M., Yang, J.C., Phan, G.Q., Hughes, M.S., Sherry, R.M., Raffeld, M., Feldman, S., Lu, L., Li, Y.F., Ngo, L.T., Goy, A., Feldman, T., Spaner, D.E., Wang, M.L., Chen, C.C., Kranick, S.M., Nath, A., Nathan, D.-A.N., Morton, K.E., Toomey, M.A., Rosenberg, S.A., 2015. Chemotherapy-refractory diffuse large B-cell lymphoma and indolent B-cell malignancies can be effectively treated with autologous $\mathrm{T}$ cells expressing an anti-CD19 chimeric antigen receptor. J. Clin. Oncol. Off. J. Am. Soc. Clin. Oncol. 33, 540-549. https://doi.org/10.1200/JCO.2014.56.2025

Koneru, M., O'Cearbhaill, R., Pendharkar, S., Spriggs, D.R., Brentjens, R.J., 2015. A phase I clinical trial of adoptive T cell therapy using IL-12 secreting MUC-16(ecto) directed chimeric antigen receptors for recurrent ovarian cancer. J. Transl. Med. 13, 102. https://doi.org/10.1186/s12967-015-0460-x

Krenciute, G., Prinzing, B.L., Yi, Z., Wu, M.-F., Liu, H., Dotti, G., Balyasnikova, I.V., Gottschalk, S., 2017. Transgenic Expression of IL15 Improves Antiglioma Activity of IL13Ra2-CAR T Cells but Results in Antigen Loss Variants. Cancer Immunol. Res. 5, 571-581. https://doi.org/10.1158/2326-6066.CIR-16-0376

Kuwana, Y., Asakura, Y., Utsunomiya, N., Nakanishi, M., Arata, Y., Itoh, S., Nagase, F., Kurosawa, Y., 1987. Expression of chimeric receptor composed of immunoglobulinderived V regions and T-cell receptor-derived $\mathrm{C}$ regions. Biochem. Biophys. Res. Commun. 149, 960-968.

LaGory, E.L., Giaccia, A.J., 2016. The ever-expanding role of HIF in tumour and stromal biology. Nat. Cell Biol. 18, 356-365. https://doi.org/10.1038/ncb3330

Lamers, C.H., Sleijfer, S., van Steenbergen, S., van Elzakker, P., van Krimpen, B., Groot, C., Vulto, A., den Bakker, M., Oosterwijk, E., Debets, R., Gratama, J.W., 2013. Treatment of metastatic renal cell carcinoma with CAIX CAR-engineered T cells: clinical evaluation and management of on-target toxicity. Mol. Ther. J. Am. Soc. Gene Ther. 21, 904-912. https://doi.org/10.1038/mt.2013.17

Lamers, C.H.J., Sleijfer, S., Vulto, A.G., Kruit, W.H.J., Kliffen, M., Debets, R., Gratama, J.W., Stoter, G., Oosterwijk, E., 2006. Treatment of metastatic renal cell carcinoma with autologous T-lymphocytes genetically retargeted against carbonic anhydrase IX: first clinical experience. J. Clin. Oncol. Off. J. Am. Soc. Clin. Oncol. 24, e20-22. https://doi.org/10.1200/JCO.2006.05.9964

Lee, D.W., Kochenderfer, J.N., Stetler-Stevenson, M., Cui, Y.K., Delbrook, C., Feldman, S.A., Fry, T.J., Orentas, R., Sabatino, M., Shah, N.N., Steinberg, S.M., Stroncek, D., 
Tschernia, N., Yuan, C., Zhang, H., Zhang, L., Rosenberg, S.A., Wayne, A.S., Mackall, C.L., 2015. T cells expressing CD19 chimeric antigen receptors for acute lymphoblastic leukaemia in children and young adults: a phase 1 dose-escalation trial. Lancet Lond. Engl. 385, 517-528. https://doi.org/10.1016/S0140-6736(14)61403-3

Lee, H.-W., Choi, H.-J., Ha, S.-J., Lee, K.-T., Kwon, Y.-G., 2013. Recruitment of monocytes/macrophages in different tumor microenvironments. Biochim. Biophys. Acta 1835, 170-179. https://doi.org/10.1016/j.bbcan.2012.12.007

Liu, X., Ranganathan, R., Jiang, S., Fang, C., Sun, J., Kim, S., Newick, K., Lo, A., June, C.H., Zhao, Y., Moon, E.K., 2016. A Chimeric Switch-Receptor Targeting PD1 Augments the Efficacy of Second-Generation CAR T Cells in Advanced Solid Tumors. Cancer Res. 76, 1578-1590. https://doi.org/10.1158/0008-5472.CAN-15-2524

Ljunggren, H.G., Kärre, K., 1990. In search of the "missing self": MHC molecules and NK cell recognition. Immunol. Today 11, 237-244.

Ljunggren, H.G., Kärre, K., 1985. Host resistance directed selectively against H-2-deficient lymphoma variants. Analysis of the mechanism. J. Exp. Med. 162, 1745-1759. https://doi.org/10.1084/jem.162.6.1745

Locke, F.L., Ghobadi, A., Jacobson, C.A., Miklos, D.B., Lekakis, L.J., Oluwole, O.O., Lin, Y., Braunschweig, I., Hill, B.T., Timmerman, J.M., Deol, A., Reagan, P.M., Stiff, P., Flinn, I.W., Farooq, U., Goy, A., McSweeney, P.A., Munoz, J., Siddiqi, T., Chavez, J.C., Herrera, A.F., Bartlett, N.L., Wiezorek, J.S., Navale, L., Xue, A., Jiang, Y., Bot, A., Rossi, J.M., Kim, J.J., Go, W.Y., Neelapu, S.S., 2018. Long-term safety and activity of axicabtagene ciloleucel in refractory large B-cell lymphoma (ZUMA-1): a single-arm, multicentre, phase 1-2 trial. Lancet Oncol. https://doi.org/10.1016/S14702045(18)30864-7

Locke, F.L., Neelapu, S.S., Bartlett, N.L., Siddiqi, T., Chavez, J.C., Hosing, C.M., Ghobadi, A., Budde, L.E., Navale, L., Aycock, J.S., Wiezorek, J., Go, W.Y., 2015. Phase 1 Clinical Results of the ZUMA-1 (KTE-C19-101) Study: A Phase 1-2 Multi-Center Study Evaluating the Safety and Efficacy of Anti-CD19 CAR T Cells (KTE-C19) in Subjects with Refractory Aggressive Non-Hodgkin Lymphoma (NHL). Blood 126, 3991-3991.

Long, A.H., Haso, W.M., Shern, J.F., Wanhainen, K.M., Murgai, M., Ingaramo, M., Smith, J.P., Walker, A.J., Kohler, M.E., Venkateshwara, V.R., Kaplan, R.N., Patterson, G.H., Fry, T.J., Orentas, R.J., Mackall, C.L., 2015. 4-1BB Costimulation Ameliorates T Cell Exhaustion Induced by Tonic Signaling of Chimeric Antigen Receptors. Nat. Med. 21, 581-590. https://doi.org/10.1038/nm.3838

Long, A.H., Highfill, S.L., Cui, Y., Smith, J.P., Walker, A.J., Ramakrishna, S., El-Etriby, R., Galli, S., Tsokos, M.G., Orentas, R.J., Mackall, C.L., 2016. Reduction of MDSCs with All-trans Retinoic Acid Improves CAR Therapy Efficacy for Sarcomas. Cancer Immunol. Res. 4, 869-880. https://doi.org/10.1158/2326-6066.CIR-15-0230

Lugli, E., Gattinoni, L., Roberto, A., Mavilio, D., Price, D.A., Restifo, N.P., Roederer, M., 2013. Identification, isolation and in vitro expansion of human and nonhuman primate $\mathrm{T}$ stem cell memory cells. Nat. Protoc. 8, 33-42. https://doi.org/10.1038/nprot.2012.143

Malmberg, K.-J., Carlsten, M., Björklund, A., Sohlberg, E., Bryceson, Y.T., Ljunggren, H.-G., 2017. Natural killer cell-mediated immunosurveillance of human cancer. Semin. Immunol. 31, 20-29. https://doi.org/10.1016/j.smim.2017.08.002

Markley, J.C., Sadelain, M., 2010. IL-7 and IL-21 are superior to IL-2 and IL-15 in promoting human $\mathrm{T}$ cell-mediated rejection of systemic lymphoma in immunodeficient mice. Blood 115, 3508-3519. https://doi.org/10.1182/blood-2009-09-241398 
Masopust, D., Choo, D., Vezys, V., Wherry, E.J., Duraiswamy, J., Akondy, R., Wang, J., Casey, K.A., Barber, D.L., Kawamura, K.S., Fraser, K.A., Webby, R.J., Brinkmann, V., Butcher, E.C., Newell, K.A., Ahmed, R., 2010. Dynamic T cell migration program provides resident memory within intestinal epithelium. J. Exp. Med. 207, 553-564. https://doi.org/10.1084/jem.20090858

Maude, S.L., Frey, N., Shaw, P.A., Aplenc, R., Barrett, D.M., Bunin, N.J., Chew, A., Gonzalez, V.E., Zheng, Z., Lacey, S.F., Mahnke, Y.D., Melenhorst, J.J., Rheingold, S.R., Shen, A., Teachey, D.T., Levine, B.L., June, C.H., Porter, D.L., Grupp, S.A., 2014. Chimeric antigen receptor T cells for sustained remissions in leukemia. N. Engl. J. Med. 371, 1507-1517. https://doi.org/10.1056/NEJMoa1407222

Maude, S.L., Hucks, G.E., Seif, A.E., Talekar, M.K., Teachey, D.T., Baniewicz, D., Callahan, C., Gonzalez, V., Nazimuddin, F., Gupta, M., Frey, N.V., Porter, D.L., Levine, B.L., Melenhorst, J.J., Lacey, S.F., June, C.H., Grupp, S.A., 2017. The effect of pembrolizumab in combination with CD19-targeted chimeric antigen receptor (CAR) T cells in relapsed acute lymphoblastic leukemia (ALL). J. Clin. Oncol. 35, 103-103. https://doi.org/10.1200/JCO.2017.35.15_suppl.103

Maude, S.L., Laetsch, T.W., Buechner, J., Rives, S., Boyer, M., Bittencourt, H., Bader, P., Verneris, M.R., Stefanski, H.E., Myers, G.D., Qayed, M., De Moerloose, B., Hiramatsu, H., Schlis, K., Davis, K.L., Martin, P.L., Nemecek, E.R., Yanik, G.A., Peters, C., Baruchel, A., Boissel, N., Mechinaud, F., Balduzzi, A., Krueger, J., June, C.H., Levine, B.L., Wood, P., Taran, T., Leung, M., Mueller, K.T., Zhang, Y., Sen, K., Lebwohl, D., Pulsipher, M.A., Grupp, S.A., 2018. Tisagenlecleucel in Children and Young Adults with B-Cell Lymphoblastic Leukemia. N. Engl. J. Med. 378, 439-448. https://doi.org/10.1056/NEJMoa1709866

Maude, S.L., Teachey, D.T., Rheingold, S.R., Shaw, P.A., Aplenc, R., Barrett, D.M., Barker, C.S., Callahan, C., Frey, N.V., Nazimuddin, F., Lacey, S.F., Zheng, Z., Levine, B., Melenhorst, J.J., Motley, L., Porter, D.L., June, C.H., Grupp, S.A., 2016. Sustained remissions with CD19-specific chimeric antigen receptor (CAR)-modified T cells in children with relapsed/refractory ALL. J. Clin. Oncol. 34, 3011-3011. https://doi.org/10.1200/JCO.2016.34.15_suppl.3011

Menger, L., Sledzinska, A., Bergerhoff, K., Vargas, F.A., Smith, J., Poirot, L., Pule, M., Hererro, J., Peggs, K.S., Quezada, S.A., 2016. TALEN-Mediated Inactivation of PD-1 in Tumor-Reactive Lymphocytes Promotes Intratumoral T-cell Persistence and Rejection of Established Tumors. Cancer Res. 76, 2087-2093. https://doi.org/10.1158/0008-5472.CAN-15-3352

Milone, M.C., Fish, J.D., Carpenito, C., Carroll, R.G., Binder, G.K., Teachey, D., Samanta, M., Lakhal, M., Gloss, B., Danet-Desnoyers, G., Campana, D., Riley, J.L., Grupp, S.A., June, C.H., 2009. Chimeric receptors containing CD137 signal transduction domains mediate enhanced survival of T cells and increased antileukemic efficacy in vivo. Mol. Ther. J. Am. Soc. Gene Ther. 17, 1453-1464. https://doi.org/10.1038/mt.2009.83

Moon, E.K., Carpenito, C., Sun, J., Wang, L.-C.S., Kapoor, V., Predina, J., Powell, D.J., Riley, J.L., June, C.H., Albelda, S.M., 2011. Expression of a functional CCR2 receptor enhances tumor localization and tumor eradication by retargeted human $\mathrm{T}$ cells expressing a mesothelin-specific chimeric antibody receptor. Clin. Cancer Res. Off. J. Am. Assoc. Cancer Res. 17, 4719-4730. https://doi.org/10.1158/1078-0432.CCR-110351

Morgan, R.A., Yang, J.C., Kitano, M., Dudley, M.E., Laurencot, C.M., Rosenberg, S.A., 2010. Case report of a serious adverse event following the administration of T cells transduced with a chimeric antigen receptor recognizing ERBB2. Mol. Ther. J. Am. Soc. Gene Ther. 18, 843-851. https://doi.org/10.1038/mt.2010.24 
Neelapu, S., 2018. 2-Year Follow-up and High-Risk Subset Analysis of Zuma-1, the Pivotal Study of Axicabtagene Ciloleucel (Axi-Cel) in Patients with Refractory Large B Cell Lymphoma. Presented at the 60th Annual Meeting and Exposition (December 1-4, 2018), ASH.

Neelapu, S.S., Locke, F.L., Bartlett, N.L., Lekakis, L.J., Miklos, D.B., Jacobson, C.A., Braunschweig, I., Oluwole, O.O., Siddiqi, T., Lin, Y., Timmerman, J.M., Stiff, P.J., Friedberg, J.W., Flinn, I.W., Goy, A., Hill, B.T., Smith, M.R., Deol, A., Farooq, U., McSweeney, P., Munoz, J., Avivi, I., Castro, J.E., Westin, J.R., Chavez, J.C., Ghobadi, A., Komanduri, K.V., Levy, R., Jacobsen, E.D., Witzig, T.E., Reagan, P., Bot, A., Rossi, J., Navale, L., Jiang, Y., Aycock, J., Elias, M., Chang, D., Wiezorek, J., Go, W.Y., 2017. Axicabtagene Ciloleucel CAR T-Cell Therapy in Refractory Large B-Cell Lymphoma. N. Engl. J. Med. 377, 2531-2544. https://doi.org/10.1056/NEJMoa1707447

Ohno, M., Ohkuri, T., Kosaka, A., Tanahashi, K., June, C.H., Natsume, A., Okada, H., 2013. Expression of miR-17-92 enhances anti-tumor activity of T-cells transduced with the anti-EGFRvIII chimeric antigen receptor in mice bearing human GBM xenografts. J. Immunother. Cancer 1, 21. https://doi.org/10.1186/2051-1426-1-21

Oosterling, S.J., van der Bij, G.J., Meijer, G.A., Tuk, C.W., van Garderen, E., van Rooijen, N., Meijer, S., van der Sijp, J.R.M., Beelen, R.H.J., van Egmond, M., 2005. Macrophages direct tumour histology and clinical outcome in a colon cancer model. J. Pathol. 207, 147-155. https://doi.org/10.1002/path.1830

Park, J.H., Riviere, I., Wang, X., Bernal, Y., Purdon, T., Halton, E., Curran, K.J., Sauter, C.S., Sadelain, M., Brentjens, R.J., 2015. Efficacy and safety of CD19-targeted 19-28z CAR modified T cells in adult patients with relapsed or refractory B-ALL. J. Clin. Oncol. 33, 7010-7010. https://doi.org/10.1200/jco.2015.33.15_suppl.7010

Paszkiewicz, P.J., Fräßle, S.P., Srivastava, S., Sommermeyer, D., Hudecek, M., Drexler, I., Sadelain, M., Liu, L., Jensen, M.C., Riddell, S.R., Busch, D.H., 2016. Targeted antibody-mediated depletion of murine CD19 CAR T cells permanently reverses B cell aplasia. J. Clin. Invest. 126, 4262-4272. https://doi.org/10.1172/JCI84813

Pegram, H.J., Purdon, T.J., van Leeuwen, D.G., Curran, K.J., Giralt, S.A., Barker, J.N., Brentjens, R.J., 2015. IL-12-secreting CD19-targeted cord blood-derived T cells for the immunotherapy of B-cell acute lymphoblastic leukemia. Leukemia 29, 415-422. https://doi.org/10.1038/leu.2014.215

Perera, L.P., Zhang, M., Nakagawa, M., Petrus, M.N., Maeda, M., Kadin, M.E., Waldmann, T.A., Perera, P.-Y., 2017. Chimeric antigen receptor modified T cells that target chemokine receptor CCR4 as a therapeutic modality for T-cell malignancies. Am. J. Hematol. 92, 892-901. https://doi.org/10.1002/ajh.24794

Philip, B., Kokalaki, E., Mekkaoui, L., Thomas, S., Straathof, K., Flutter, B., Marin, V., Marafioti, T., Chakraverty, R., Linch, D., Quezada, S.A., Peggs, K.S., Pule, M., 2014. A highly compact epitope-based marker/suicide gene for easier and safer T-cell therapy. Blood 124, 1277-1287. https://doi.org/10.1182/blood-2014-01-545020

Porter, D.L., Hwang, W.-T., Frey, N.V., Lacey, S.F., Shaw, P.A., Loren, A.W., Bagg, A., Marcucci, K.T., Shen, A., Gonzalez, V., Ambrose, D., Grupp, S.A., Chew, A., Zheng, Z., Milone, M.C., Levine, B.L., Melenhorst, J.J., June, C.H., 2015. Chimeric antigen receptor $\mathrm{T}$ cells persist and induce sustained remissions in relapsed refractory chronic lymphocytic leukemia. Sci. Transl. Med. 7, 303ra139. https://doi.org/10.1126/scitranslmed.aac5415

Porter, D.L., Levine, B.L., Kalos, M., Bagg, A., June, C.H., 2011. Chimeric antigen receptormodified T cells in chronic lymphoid leukemia. N. Engl. J. Med. 365, 725-733. https://doi.org/10.1056/NEJMoa1103849 
Pule, M.A., Savoldo, B., Myers, G.D., Rossig, C., Russell, H.V., Dotti, G., Huls, M.H., Liu, E., Gee, A.P., Mei, Z., Yvon, E., Weiss, H.L., Liu, H., Rooney, C.M., Heslop, H.E., Brenner, M.K., 2008. Virus-specific T cells engineered to coexpress tumor-specific receptors: persistence and antitumor activity in individuals with neuroblastoma. Nat. Med. 14, 1264-1270. https://doi.org/10.1038/nm.1882

Pulè, M.A., Straathof, K.C., Dotti, G., Heslop, H.E., Rooney, C.M., Brenner, M.K., 2005. A chimeric $\mathrm{T}$ cell antigen receptor that augments cytokine release and supports clonal expansion of primary human T cells. Mol. Ther. J. Am. Soc. Gene Ther. 12, 933-941. https://doi.org/10.1016/j.ymthe.2005.04.016

Ren, J., Zhang, X., Liu, X., Fang, C., Jiang, S., June, C.H., Zhao, Y., 2017. A versatile system for rapid multiplex genome-edited CAR T cell generation. Oncotarget 8, 17002-17011. https://doi.org/10.18632/oncotarget.15218

Research, C. for B.E. and, n.d. Approved Products - YESCARTA (axicabtagene ciloleucel) [WWW Document].

URL https://www.fda.gov/biologicsbloodvaccines/cellulargenetherapyproducts/approvedpr oducts/ucm581222.htm https://www.fda.gov/biologicsbloodvaccines/cellulargenetherapyproducts/approvedpr oducts/ucm581222.htm (accessed 1.2.19a).

Research, C. for B.E. and, n.d. Approved Products - KYMRIAH (tisagenlecleucel) [WWW Document].

URL https://www.fda.gov/BiologicsBloodVaccines/CellularGeneTherapyProducts/Approv edProducts/ucm573706.htm

https://www.fda.gov/biologicsbloodvaccines/cellulargenetherapyproducts/approvedpr oducts/ucm573706.htm (accessed 1.2.19b).

Rincon-Orozco, B., Kunzmann, V., Wrobel, P., Kabelitz, D., Steinle, A., Herrmann, T., 2005. Activation of V gamma 9V delta $2 \mathrm{~T}$ cells by NKG2D. J. Immunol. Baltim. Md 1950 $175,2144-2151$.

Rodgers, D.T., Mazagova, M., Hampton, E.N., Cao, Y., Ramadoss, N.S., Hardy, I.R., Schulman, A., Du, J., Wang, F., Singer, O., Ma, J., Nunez, V., Shen, J., Woods, A.K., Wright, T.M., Schultz, P.G., Kim, C.H., Young, T.S., 2016. Switch-mediated activation and retargeting of CAR-T cells for B-cell malignancies. Proc. Natl. Acad. Sci. U. S. A. 113, E459-468. https://doi.org/10.1073/pnas.1524155113

Ruella, M., Klichinsky, M., Kenderian, S.S., Shestova, O., Ziober, A., Kraft, D.O., Feldman, M., Wasik, M.A., June, C.H., Gill, S., 2017. Overcoming the Immunosuppressive Tumor Microenvironment of Hodgkin Lymphoma Using Chimeric Antigen Receptor T Cells. Cancer Discov. 7, 1154-1167. https://doi.org/10.1158/2159-8290.CD-16-0850

Ruella, M., Xu, J., Barrett, D.M., Fraietta, J.A., Reich, T.J., Ambrose, D.E., Klichinsky, M., Shestova, O., Patel, P.R., Kulikovskaya, I., Nazimuddin, F., Bhoj, V.G., Orlando, E.J., Fry, T.J., Bitter, H., Maude, S.L., Levine, B.L., Nobles, C.L., Bushman, F.D., Young, R.M., Scholler, J., Gill, S.I., June, C.H., Grupp, S.A., Lacey, S.F., Melenhorst, J.J., 2018. Induction of resistance to chimeric antigen receptor $\mathrm{T}$ cell therapy by transduction of a single leukemic B cell. Nat. Med. 24, 1499. https://doi.org/10.1038/s41591-0180201-9

Ruggeri, L., Aversa, F., Martelli, M.F., Velardi, A., 2006. Allogeneic hematopoietic transplantation and natural killer cell recognition of missing self. Immunol. Rev. 214, 202-218. https://doi.org/10.1111/j.1600-065X.2006.00455.x

Ruggeri, L., Capanni, M., Urbani, E., Perruccio, K., Shlomchik, W.D., Tosti, A., Posati, S., Rogaia, D., Frassoni, F., Aversa, F., Martelli, M.F., Velardi, A., 2002. Effectiveness of donor natural killer cell alloreactivity in mismatched hematopoietic transplants. Science 295, 2097-2100. https://doi.org/10.1126/science.1068440 
Sakemura, R., Terakura, S., Watanabe, K., Julamanee, J., Takagi, E., Miyao, K., Koyama, D., Goto, T., Hanajiri, R., Nishida, T., Murata, M., Kiyoi, H., 2016. A Tet-On Inducible System for Controlling CD19-Chimeric Antigen Receptor Expression upon Drug Administration. Cancer Immunol. Res. 4, 658-668. https://doi.org/10.1158/23266066.CIR-16-0043

Sallusto, F., Lenig, D., Förster, R., Lipp, M., Lanzavecchia, A., 1999. Two subsets of memory T lymphocytes with distinct homing potentials and effector functions. Nature 401, 708712. https://doi.org/10.1038/44385

Salter, A.I., Ivey, R.G., Kennedy, J.J., Voillet, V., Rajan, A., Alderman, E.J., Voytovich, U.J., Lin, C., Sommermeyer, D., Liu, L., Whiteaker, J.R., Gottardo, R., Paulovich, A.G., Riddell, S.R., 2018. Phosphoproteomic analysis of chimeric antigen receptor signaling reveals kinetic and quantitative differences that affect cell function. Sci. Signal. 11. https://doi.org/10.1126/scisignal.aat6753

Siddiqui, I., Erreni, M., van Brakel, M., Debets, R., Allavena, P., 2016. Enhanced recruitment of genetically modified CX3CR1-positive human T cells into Fractalkine/CX3CL1 expressing tumors: importance of the chemokine gradient. J. Immunother. Cancer 4. https://doi.org/10.1186/s40425-016-0125-1

Sommermeyer, D., Hudecek, M., Kosasih, P.L., Gogishvili, T., Maloney, D.G., Turtle, C.J., Riddell, S.R., 2016. Chimeric antigen receptor-modified T cells derived from defined CD8+ and CD4+ subsets confer superior antitumor reactivity in vivo. Leukemia 30, 492-500. https://doi.org/10.1038/leu.2015.247

Sotillo, E., Barrett, D.M., Black, K.L., Bagashev, A., Oldridge, D., Wu, G., Sussman, R., Lanauze, C., Ruella, M., Gazzara, M.R., Martinez, N.M., Harrington, C.T., Chung, E.Y., Perazzelli, J., Hofmann, T.J., Maude, S.L., Raman, P., Barrera, A., Gill, S., Lacey, S.F., Melenhorst, J.J., Allman, D., Jacoby, E., Fry, T., Mackall, C., Barash, Y., Lynch, K.W., Maris, J.M., Grupp, S.A., Thomas-Tikhonenko, A., 2015. Convergence of Acquired Mutations and Alternative Splicing of CD19 Enables Resistance to CART19 Immunotherapy. Cancer Discov. 5, 1282-1295. https://doi.org/10.1158/21598290.CD-15-1020

Spolski, R., Kim, H.-P., Zhu, W., Levy, D.E., Leonard, W.J., 2009. IL-21 mediates suppressive effects via its induction of IL-10. J. Immunol. Baltim. Md 1950 182, 2859-2867. https://doi.org/10.4049/jimmunol.0802978

Spranger, S., Bao, R., Gajewski, T.F., 2015. Melanoma-intrinsic $\beta$-catenin signalling prevents anti-tumour immunity. Nature 523, 231-235. https://doi.org/10.1038/nature14404

Suarez, E.R., Chang, D.K., Sun, J., Sui, J., Freeman, G.J., Signoretti, S., Zhu, Q., Marasco, W.A., 2016. Chimeric antigen receptor T cells secreting anti-PD-L1 antibodies more effectively regress renal cell carcinoma in a humanized mouse model. Oncotarget 7 , 34341-34355. https://doi.org/10.18632/oncotarget.9114

Tasian, S.K., Kenderian, S.S., Shen, F., Ruella, M., Shestova, O., Kozlowski, M., Li, Y., Schrank-Hacker, A., Morrissette, J.J.D., Carroll, M., June, C.H., Grupp, S.A., Gill, S., 2017. Optimized depletion of chimeric antigen receptor T cells in murine xenograft models of human acute myeloid leukemia. Blood 129, 2395-2407. https://doi.org/10.1182/blood-2016-08-736041

Till, B.G., Jensen, M.C., Wang, J., Chen, E.Y., Wood, B.L., Greisman, H.A., Qian, X., James, S.E., Raubitschek, A., Forman, S.J., Gopal, A.K., Pagel, J.M., Lindgren, C.G., Greenberg, P.D., Riddell, S.R., Press, O.W., 2008. Adoptive immunotherapy for indolent non-Hodgkin lymphoma and mantle cell lymphoma using genetically modified autologous CD20-specific $\mathrm{T}$ cells. Blood 112, 2261-2271. https://doi.org/10.1182/blood-2007-12-128843 
Turtle, C.J., Hanafi, L.-A., Berger, C., Gooley, T.A., Cherian, S., Hudecek, M., Sommermeyer, D., Melville, K., Pender, B., Budiarto, T.M., Robinson, E., Steevens, N.N., Chaney, C., Soma, L., Chen, X., Yeung, C., Wood, B., Li, D., Cao, J., Heimfeld, S., Jensen, M.C., Riddell, S.R., Maloney, D.G., 2016. CD19 CAR-T cells of defined CD4+:CD8+ composition in adult B cell ALL patients. J. Clin. Invest. 126, 2123-2138. https://doi.org/10.1172/JCI85309

Urbanska, K., Lanitis, E., Poussin, M., Lynn, R.C., Gavin, B.P., Kelderman, S., Yu, J., Scholler, N., Powell, D.J., 2012. A universal strategy for adoptive immunotherapy of cancer through use of a novel T-cell antigen receptor. Cancer Res. 72, 1844-1852. https://doi.org/10.1158/0008-5472.CAN-11-3890

Vogler, I., Newrzela, S., Hartmann, S., Schneider, N., von Laer, D., Koehl, U., Grez, M., 2010. An improved bicistronic CD20/tCD34 vector for efficient purification and in vivo depletion of gene-modified T cells for adoptive immunotherapy. Mol. Ther. J. Am. Soc. Gene Ther. 18, 1330-1338. https://doi.org/10.1038/mt.2010.83

Vormittag, P., Gunn, R., Ghorashian, S., Veraitch, F.S., 2018. A guide to manufacturing CAR $\mathrm{T}$ cell therapies. Curr. Opin. Biotechnol. 53, 164-181. https://doi.org/10.1016/j.copbio.2018.01.025

Wagner, D.L., Amini, L., Wendering, D.J., Burkhardt, L.-M., Akyüz, L., Reinke, P., Volk, H.D., Schmueck-Henneresse, M., 2018. High prevalence of Streptococcus pyogenes Cas9-reactive $\mathrm{T}$ cells within the adult human population. Nat. Med. 1. https://doi.org/10.1038/s41591-018-0204-6

Wang, J., Jensen, M., Lin, Y., Sui, X., Chen, E., Lindgren, C.G., Till, B., Raubitschek, A., Forman, S.J., Qian, X., James, S., Greenberg, P., Riddell, S., Press, O.W., 2007. Optimizing adoptive polyclonal $\mathrm{T}$ cell immunotherapy of lymphomas, using a chimeric T cell receptor possessing CD28 and CD137 costimulatory domains. Hum. Gene Ther. 18, 712-725. https://doi.org/10.1089/hum.2007.028

Wang, X., Chang, W.-C., Wong, C.W., Colcher, D., Sherman, M., Ostberg, J.R., Forman, S.J., Riddell, S.R., Jensen, M.C., 2011. A transgene-encoded cell surface polypeptide for selection, in vivo tracking, and ablation of engineered cells. Blood 118, 1255-1263. https://doi.org/10.1182/blood-2011-02-337360

Wrobel, P., Shojaei, H., Schittek, B., Gieseler, F., Wollenberg, B., Kalthoff, H., Kabelitz, D., Wesch, D., 2007. Lysis of a broad range of epithelial tumour cells by human gamma delta T cells: involvement of NKG2D ligands and T-cell receptor- versus NKG2Ddependent recognition. Scand. J. Immunol. 66, 320-328. https://doi.org/10.1111/j.1365-3083.2007.01963.x

Wu, C.-Y., Roybal, K.T., Puchner, E.M., Onuffer, J., Lim, W.A., 2015. Remote control of therapeutic $\mathrm{T}$ cells through a small molecule-gated chimeric receptor. Science 350, aab4077. https://doi.org/10.1126/science.aab4077

Ying, Z.-T., Chang, L.-J., Kuo, H.-H., Liu, Y.-C., Song, Y.-Q., Wang, X.-P., Liu, W.-P., Zheng, W., Xie, Y., Lin, N.-J., Tu, M.-F., Ping, L.-Y., Zhang, C., Huang, H.-Y., Zhu, J., 2015. 415. First-In-Patient Proof of Safety and Efficacy of a 4th Generation Chimeric Antigen Receptor-Modified T Cells for the Treatment of Relapsed or Refractory CD30 Positive Lymphomas. Mol. Ther. 23, S164. https://doi.org/10.1016/S1525-0016(16)34024-2

Zhang, Y., Zhang, X., Cheng, C., Mu, W., Liu, Xiaojuan, Li, N., Wei, X., Liu, Xiang, Xia, C., Wang, H., 2017. CRISPR-Cas9 mediated LAG-3 disruption in CAR-T cells. Front. Med. 11, 554-562. https://doi.org/10.1007/s11684-017-0543-6

Zhao, Y., Wang, Q.J., Yang, S., Kochenderfer, J.N., Zheng, Z., Zhong, X., Sadelain, M., Eshhar, Z., Rosenberg, S.A., Morgan, R.A., 2009. A herceptin-based chimeric antigen receptor with modified signaling domains leads to enhanced survival of transduced $\mathrm{T}$ 
lymphocytes and antitumor activity. J. Immunol. Baltim. Md 1950 183, 5563-5574. https://doi.org/10.4049/jimmunol.0900447

Zhong, X.-S., Matsushita, M., Plotkin, J., Riviere, I., Sadelain, M., 2010. Chimeric antigen receptors combining 4-1BB and $\mathrm{CD} 28$ signaling domains augment PI3kinase/AKT/Bcl-XL activation and CD8+ T cell-mediated tumor eradication. Mol. Ther. J. Am. Soc. Gene Ther. 18, 413-420. https://doi.org/10.1038/mt.2009.210 
Figure 1 TCR structure and T cell activation. The TCR/CD3 complex comprises of variable $\alpha$ and $\beta$ chains associated with one transmembrane CD3 $\gamma \varepsilon$ heterodimer, one transmembrane $\mathrm{CD} 3 \delta \varepsilon$ heterodimer and one transmembrane CD3 $\zeta \zeta$ homodimer (Nurieva et al., 2009). T cell activation is initiated when the TCR/CD3 complex on the T cell interacts with the MHC molecule on the APC surface. For full T cell activation signals 1 and 2 are required from the TCR/CD3 (signal 1) and the co-stimulatory receptors (signal 2) CD28 (binding to CD80 and CD86), 4-1BB (binding to 4-1B ligand), ICOS (binding to ICOS ligand), CD27 (binding to CD70) and OX40 (binding to OX40 ligand). Signal 3 which is transmitted by cytokine receptors is crucial for survival and differentiation. The binding of peptide-MHC complexes to the TCR initiate a signaling cascade propagated through the cytosol and the nucleus of the cell reviewed in (Malissen et al., 2014). TM, transmembrane; ICOS, inducible co-stimulator; $\mathrm{CD}$, cluster of differentiation.

Figure 2 CAR generations. CAR comprises of an extracellular, a hinge/transmembrane and an intracellular domain. The extracellular portion of the CAR consists of only the variable regions of the light and heavy chain of an antibody that are fused via a flexible linker ( $\mathrm{scFv}$ ). The flexible hinge domain, used alone or in conjunction with a spacer, is a short peptide fragment that provides conformational freedom to facilitate binding to the target antigen on the tumor cell and together with the transmembrane domain bridge the scFv to the intracellular domain. The intracellular domain comprises of a TCR-derived CD3 $\zeta$ domain and one or more co-stimulatory domains for intracellular signaling, depending on the generation of the CAR construct. First generation CARs contain a single CD3 $\zeta$ domain. Second and third generation CARs incorporate one or more co-stimulatory domains respectively. While the vast amount of studies have looked into CD28 and 4-1BB, other costimulatory domains are currently being evaluated (Foster et al., 2017; Song et al., 2012).

Figure 3 Inducible switches. A, Addition of a dimerizing drug activates iCaspase 9 (iCasp9) signaling pathway which results in apoptosis of CAR-T cells (Straathof et al., 2005). B, CAR-T cells expressing the herpes simplex virus thymidine kinase (HSV-TK) suicide gene can be eliminated by the administration of ganciclovir (GCV) which is metabolized into a toxic purine analogue. C, CAR-T cells expressing truncated epithelial growth factor receptor (tEGFR) or CD20 can be tagged with the monoclonal antibodies Cetuximab or Rituximab that bind tEGFR and CD20 respectively. RQR8 is a minimal marker/suicide gene combining epitopes from CD20 (to bind Rituximab for elimination of CAR-T cells) and CD34 (to serve as a selection marker) (Labanieh et al., 2018).

Figure 4 Inducible systems. A, The Tet ON system is controlled by the addition or removal of tetracycline that allows the reversible expression of CD19 CAR. In the presence of tetracycline (Tet), the reverse tetracycline-controlled trans activator (rtTA) induces the expression of the CD19 CAR. B, CAR domains are split in individual, non-functional receptors attached on an FK506 binding protein (FKBP) domain and an FKBP12-rapamycin binding domain (FRB). CAR assembly can be subsequently induced via the addition of a dimerizing drug such as rapamycin.

Figure 5 Logic states. A, Upon binding antigen A, synNotch undergoes conformational changes that result in the release of the transcription factor (TF). TF in turn translocates to the nucleus of the cell and induces the expression of CAR for antigen B (Roybal et al., 2016). B, 
Inhibitory CAR (iCAR) reduces $\mathrm{T}$ cell response in the presence of a healthy antigen due to the presence of an inhibitory domain such as PD-1 or CTLA-4 that is fused to the antigenbinding domain recognizing the healthy antigen. CAR-T response occurs only in the simultaneous presence of a tumor associated antigen (TAA) and the absence of the healthy antigen (AND-NOT Gate). C, OR Gate CARs can be activated in the presence of either antigen A or antigen B. D, Dual CARs express two separate CARs with different ligand binding targets. One CAR contains only the domain for signal 1 while the second CAR contains only the co-stimulatory domains. CAR-T activation occurs only in the presence of both antigens. E, Tandem CARs (Tan CARs) express a single CAR consisting of two linked scFvs in tandem fused to co-stimulatory and signal 1 domains. Similarly to dual CARs, CAR$\mathrm{T}$ activation occurs only in the presence of both antigens adapted from (Labanieh et al., 2018).

Figure 6 Tumor microenvironment-sensing (TME) CARs. A, Masked CARs are kept in an OFF state through a targetable peptide that masks the scFv region of the CAR. Once CAR-Ts reach the TME, tumor-specific proteases cleave the peptide and expose the scFv. B, Oxygensensing CARs contain a hypoxia-inducible factor (HIF) domain that is targeted for degradation in the presence of oxygen (normoxia). CAR expression is stabilized in the hypoxic (low oxygen) conditions of the TME adapted from (Labanieh et al., 2018).

Figure 7 Armored CARs. A, CAR-T cells armored with anti-tumor cytokines. Cytokine expression may be constitutive or induced subsequent of $\mathrm{T}$ cell activation. Localized production of pro-inflammatory cytokines can recruit other immune cells to tumor sites where they may enhance anti-tumor activity. IL, interleukin. B, CAR-T cells may be engineered to express chemokine receptors to enhance trafficking into tumor tissue and homing to tumor cells.

Figure 8 Strategies improving efficacy and anti-immunosuppression. A, CAR-T cells engineered to be resistant to immunosuppression by lacking expression of immune checkpoint molecules (e.g. PD-1, CTLA-4, LAG-3, TIM-3), by expressing immune checkpoint switch receptors or dominant-negative receptors, or by being administered with antibodies or inhibitors that result in reduction of immune checkpoint signaling. B, CAR-T cells can be engineered to target cells of the tumor microenvironment (TME) that may therefore enhance the infiltration of CAR-T cells directed against tumor cells. Examples include cancer-associated fibroblasts, tumor endothelial cells, tumor-associated macrophages and $\mathrm{T}$ regulatory cells. TIM-3; T-cell immunoglobulin protein-3. 
Signal 1

Signal 2

Signal 3

$\alpha \beta$

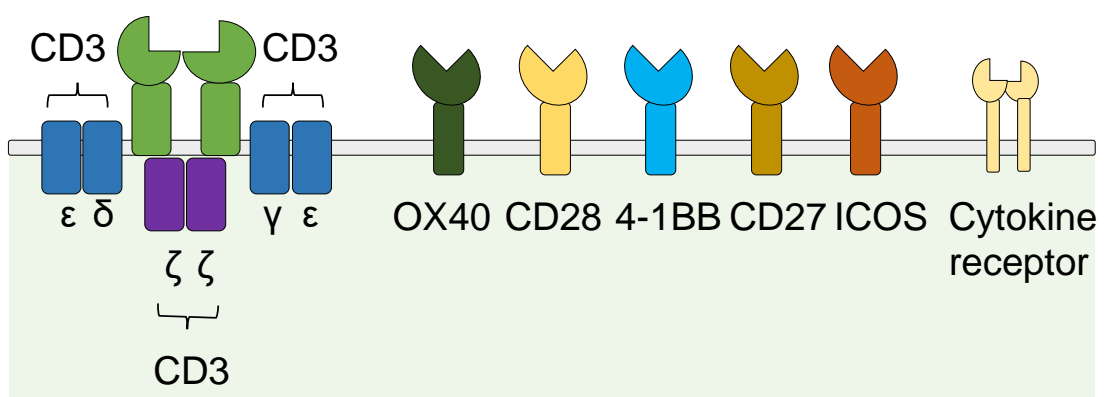

Figure 1

TCR/CD3 complex Co-stimulatory receptors 


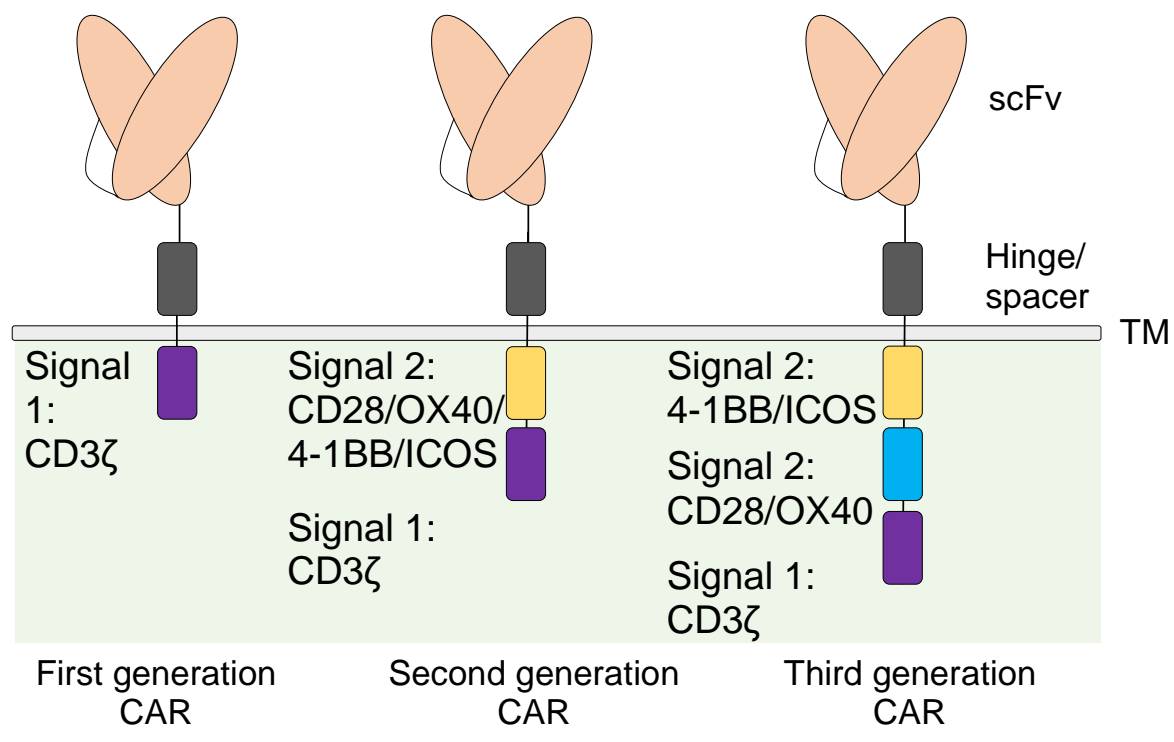



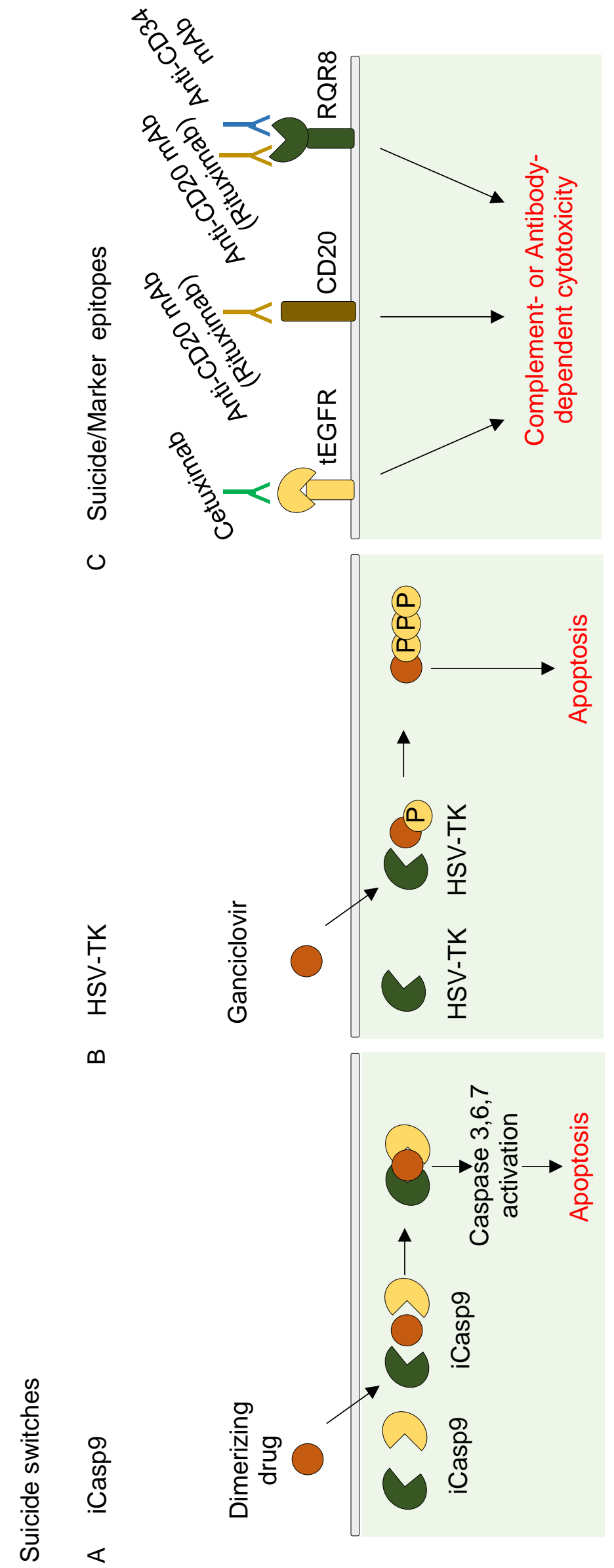

Figure 3 


\section{A Tet ON system}

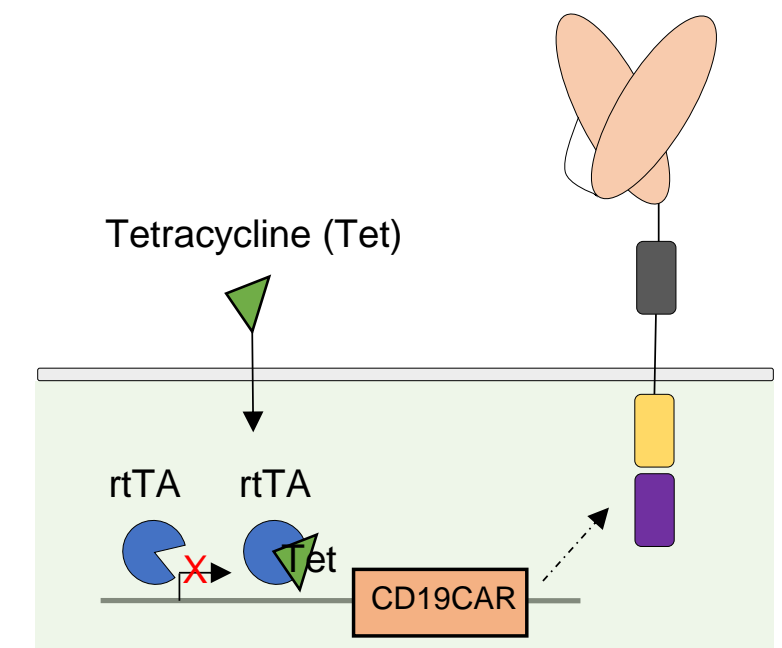

B Chemically-induced assembly

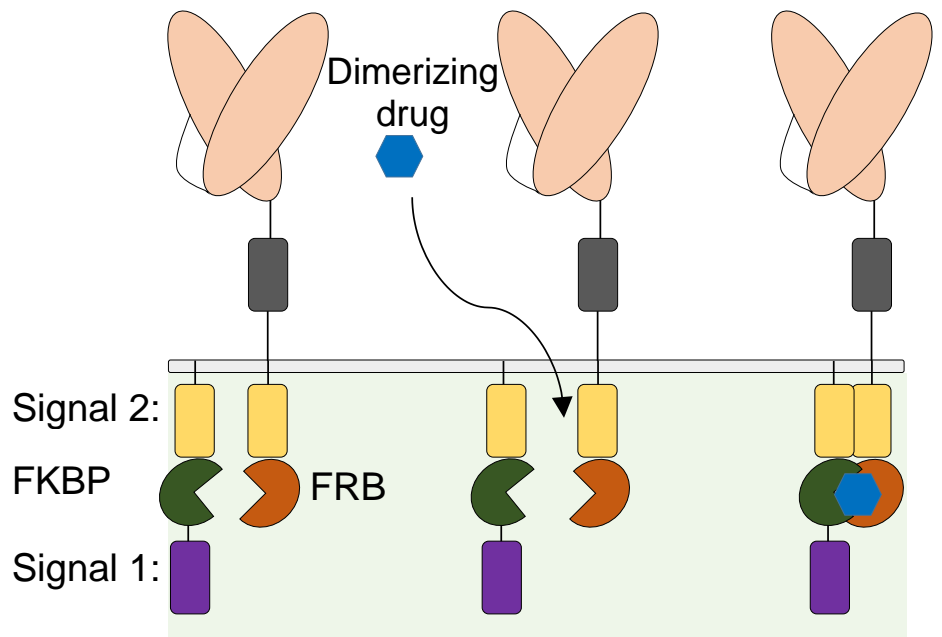




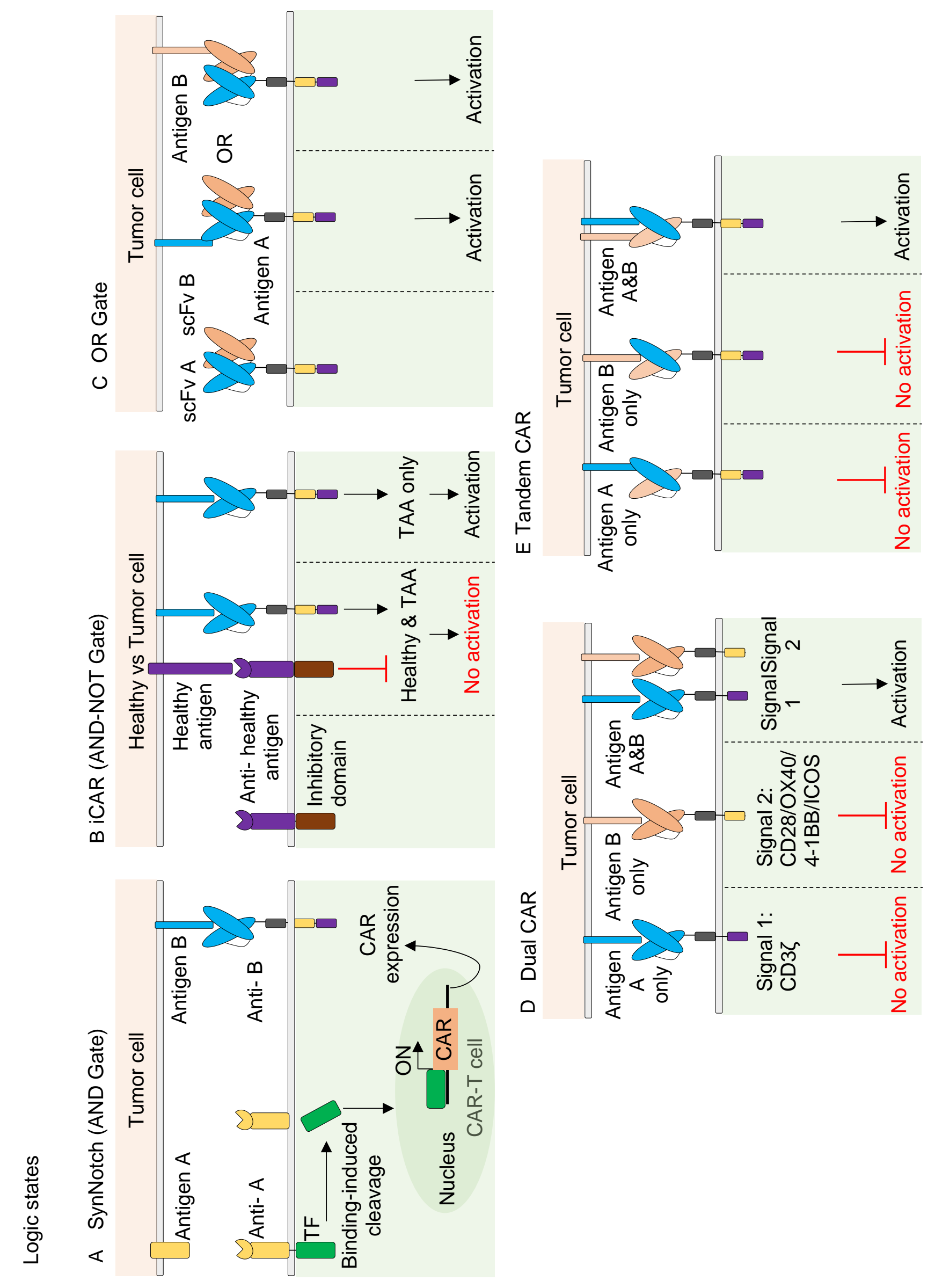

Figure 5 
TME sensing
A Masked CAR
B Oxygen-sensing CAR

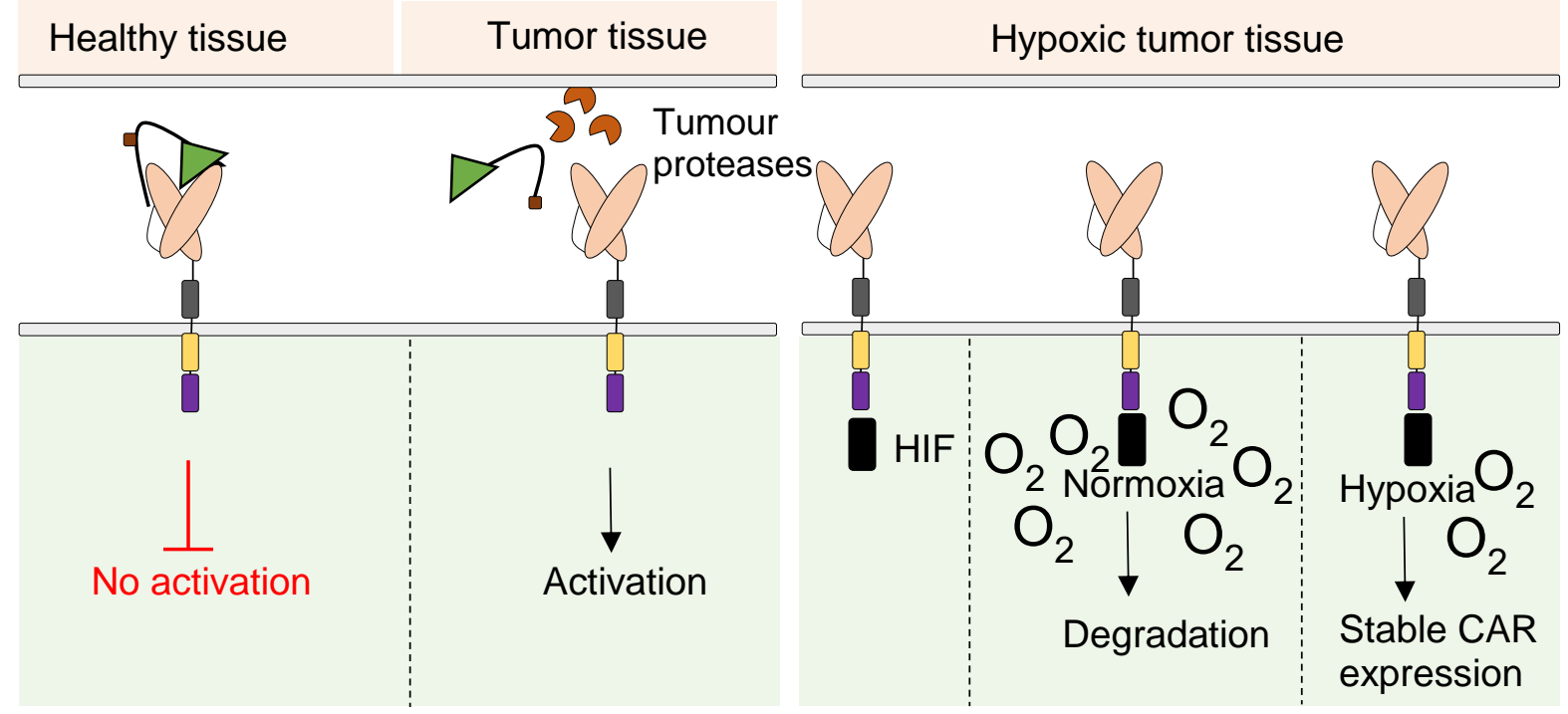




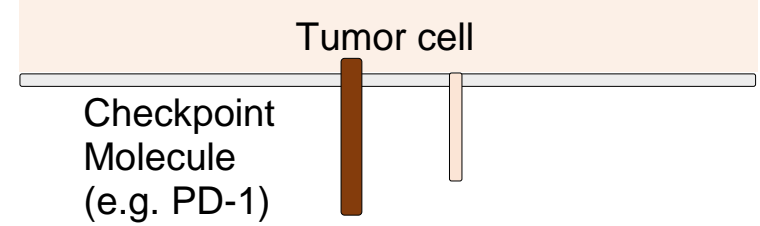

TME cell

CAR

No inhibitory signal 
Table 1 Heterogeneity of the human T cell compartment. The combinatorial expression of multiple markers on the cell surface, as determined by multicolor flow cytometry, allows to identify 6 major T cell subsets. T cells that have not yet encountered an antigen and are therefore not activated, are called naïve $\mathrm{T}\left(\mathrm{T}_{\mathrm{N}}\right)$ cells. Activated $\mathrm{T}$ cells rapidly proliferate and exert effector functions such as cell-mediated cytotoxicity and cytokine production. While differentiating (through activation) from $\mathrm{T}_{\mathrm{N}}$, $\mathrm{T}_{\mathrm{SCM}}$ to $\mathrm{T}_{\mathrm{CM}}, \mathrm{T}_{\mathrm{RM}} / \mathrm{TM}_{\mathrm{M}}, \mathrm{T}_{\mathrm{EM}}$ and culminating in $\mathrm{T}_{\mathrm{EF}}$ cells, memory $\mathrm{T}$ cells progressively lose or acquire specific functions such as self-renewal and survival. $\mathrm{T}_{\mathrm{N}}$; naïve, $\mathrm{T}_{\mathrm{SCM}}$; stem cell memory, $\mathrm{T}_{\mathrm{CM}}$; central memory, $\mathrm{T}_{\mathrm{RM}} / \mathrm{TM}_{\mathrm{M}}$; resident memory/ tissue memory, TEM; effector memory, TEF; effector; $\mathrm{CD}$, cluster of differentiation.

\begin{tabular}{|c|c|c|c|c|c|c|}
\hline & $T_{N}$ & $T_{\text {scm }}$ & $T_{\mathrm{CM}}$ & $T_{R M / T M}$ & $T_{\text {EM }}$ & $T_{\text {EF }}$ \\
\hline CD45RO & - & - & + & + & + & - \\
\hline CD45RA & + & + & - & - & - & + \\
\hline CCR7 & + & + & + & - & - & - \\
\hline CD62L & + & + & + & - & - & - \\
\hline CD28 & + & + & + & + & - & - \\
\hline CD95 & - & + & + & + & + & + \\
\hline
\end{tabular}


Table 2 Summary of clinical trials cited. iCasp9; i Caspase9, GD2; disialoganglioside, TRBC1; T cell receptor beta constant 1, , EGFRt; truncated epithelial growth factor receptor, BCMA; B cell maturation antigen, PD-1; programmed cell death-1; PD-L1; programmed cell death-ligand 1, HER2; human epidermal growth factor 2, NK; natural killer, FOLFOX; folinic acid, fluorouracil, oxaliplatin.

\begin{tabular}{|c|c|c|c|c|}
\hline $\begin{array}{l}\text { Clinical trial } \\
\text { number } \\
\text { (NCT) }\end{array}$ & $\begin{array}{l}\text { Enrolled } \\
\text { patients }\end{array}$ & $\begin{array}{l}\text { Phase } \\
\text { of } \\
\text { clinical } \\
\text { trial }\end{array}$ & Sponsor & Modality \\
\hline $\begin{array}{l}\text { NCT02435849, } \\
\text { ELIANA, } \\
\text { CTL019 }\end{array}$ & 81 & II & $\begin{array}{l}\text { Novartis } \\
\text { Pharmaceuticals }\end{array}$ & CD19 CAR \\
\hline $\begin{array}{l}\text { NCT02348216, } \\
\text { ZUMA-1, } \\
\text { KTE-C19 }\end{array}$ & 290 & $\mathrm{I} / \mathrm{II}$ & $\begin{array}{l}\text { Kite, A Gilead } \\
\text { Company }\end{array}$ & CD19 CAR \\
\hline NCT01626495 & 76 & $\mathrm{I} / \mathrm{II}$ & $\begin{array}{l}\text { University of } \\
\text { Pennsylvania }\end{array}$ & CD19 CAR \\
\hline NCT03579927 & 36 & $\mathrm{I} / \mathrm{II}$ & $\begin{array}{l}\text { M.D. Anderson } \\
\text { Cancer Center }\end{array}$ & CD19 CAR, iCasp9 \\
\hline NCT02414269 & 66 & I & $\begin{array}{l}\text { Memorial Sloan } \\
\text { Kettering } \\
\text { Cancer Center }\end{array}$ & $\begin{array}{l}\text { Mesothelin CAR, } \\
\text { iCasp9 }\end{array}$ \\
\hline NCT02107963 & 15 & I & $\begin{array}{l}\text { National Cancer } \\
\text { Institute (NCI) }\end{array}$ & GD2 CAR,iCasp9 \\
\hline $\begin{array}{l}\text { NCT01822652, } \\
\text { GRAIN }\end{array}$ & 11 & I & $\begin{array}{l}\text { Baylor College } \\
\text { of Medicine }\end{array}$ & GD2 CAR,iCasp9 \\
\hline NCT03590574 & 55 & $\mathrm{I} / \mathrm{II}$ & Autolus & TRBC1 CAR, RQR8 \\
\hline $\begin{array}{l}\text { NCT02746952, } \\
\text { CALM, } \\
\text { UCART19 }\end{array}$ & 40 & I & $\begin{array}{l}\text { Institut de } \\
\text { Recherches } \\
\text { Internationales } \\
\text { Servier }\end{array}$ & $\begin{array}{l}\text { CD19 CAR, RQR8, } \\
\text { allogeneic }\end{array}$ \\
\hline NCT03085173 & 37 & I & $\begin{array}{l}\text { Memorial Sloan } \\
\text { Kettering } \\
\text { Cancer Center }\end{array}$ & CD19 CAR, EGFRt \\
\hline NCT03618381 & 36 & I & $\begin{array}{l}\text { Seattle } \\
\text { Children's } \\
\text { Hospital }\end{array}$ & CD19 CAR, EGFRt \\
\hline NCT02051257 & 51 & I & $\begin{array}{l}\text { City of Hope } \\
\text { Medical Center }\end{array}$ & CD19 CAR, EGFRt \\
\hline NCT03070327 & 36 & I & $\begin{array}{l}\text { Memorial Sloan } \\
\text { Kettering } \\
\text { Cancer Center }\end{array}$ & BCMA CAR, EGFRt \\
\hline NCT02028455 & 80 & $\mathrm{I} / \mathrm{II}$ & $\begin{array}{l}\text { Seattle } \\
\text { Children's } \\
\text { Hospital }\end{array}$ & CD19 CAR, EGFRt \\
\hline NCT02146924 & 22 & I & $\begin{array}{l}\text { City of Hope } \\
\text { Medical Center }\end{array}$ & CD19 CAR, EGFRt \\
\hline
\end{tabular}




\begin{tabular}{|c|c|c|c|c|}
\hline NCT01865617 & 203 & $\mathrm{I} / \mathrm{II}$ & $\begin{array}{l}\text { Fred } \\
\text { Hutchinson } \\
\text { Cancer } \\
\text { Research Center }\end{array}$ & CD19 CAR, EGFRt \\
\hline NCT02937844 & 20 & I & $\begin{array}{l}\text { Beijing Sanbo } \\
\text { Brain Hospital }\end{array}$ & PD-1 CAR, EGFRt \\
\hline NCT03638167 & 36 & I & $\begin{array}{l}\text { Seattle } \\
\text { Children's } \\
\text { Hospital }\end{array}$ & EGFR CAR, EGFRt \\
\hline NCT02311621 & 40 & I & $\begin{array}{l}\text { Seattle } \\
\text { Children's } \\
\text { Hospital }\end{array}$ & CD171 CAR, EGFRt \\
\hline NCT03114670 & 20 & I & $\begin{array}{l}\text { Affiliated } \\
\text { Hospital to } \\
\text { Academy of } \\
\text { Military } \\
\text { Medical } \\
\text { Sciences }\end{array}$ & CD123 CAR, EGFRt \\
\hline NCT02159495 & 42 & I & $\begin{array}{l}\text { City of Hope } \\
\text { Medical Center }\end{array}$ & CD123CAR, EGFRt \\
\hline NCT03233854 & 57 & I & $\begin{array}{l}\text { Crystal } \\
\text { Mackall, MD }\end{array}$ & CD19/CD22 CAR \\
\hline NCT03241940 & 50 & I & $\begin{array}{l}\text { Crystal } \\
\text { Mackall, MD }\end{array}$ & CD19/CD22 CAR \\
\hline NCT03463928 & 10 & I & $\begin{array}{l}\text { Chinese PLA } \\
\text { General } \\
\text { Hospital }\end{array}$ & CD19/CD22 CAR \\
\hline NCT03271515 & 20 & I & $\begin{array}{l}\text { Beijing Doing } \\
\text { Biomedical Co., } \\
\text { Ltd. }\end{array}$ & CD19/CD20 CAR \\
\hline NCT03767751 & 80 & $\mathrm{I} / \mathrm{II}$ & $\begin{array}{l}\text { Chinese PLA } \\
\text { General } \\
\text { Hospital }\end{array}$ & CD38/BCMA CAR \\
\hline NCT02498912 & 30 & I & $\begin{array}{l}\text { Memorial Sloan } \\
\text { Kettering } \\
\text { Cancer Center }\end{array}$ & $\begin{array}{l}\text { MUC16 }{ }^{\text {ecto }} \text { CAR/EGFRt/ } \\
\text { IL-12-secreting }\end{array}$ \\
\hline NCT02650999 & 12 & I/II & $\begin{array}{l}\text { Abramson } \\
\text { Cancer Center } \\
\text { of the } \\
\text { University of } \\
\text { Pennsylvania }\end{array}$ & $\begin{array}{l}\text { PD-1 block } \\
\text { (pembrolizumab)/CD19 } \\
\text { CAR }\end{array}$ \\
\hline $\begin{array}{l}\text { NCT02926833, } \\
\text { ZUMA-6 }\end{array}$ & 37 & I/II & $\begin{array}{l}\text { Kite, A Gilead } \\
\text { Company }\end{array}$ & $\begin{array}{l}\text { PD-L1 block } \\
\text { (atezolizumab)/ CD19 } \\
\text { CAR }\end{array}$ \\
\hline NCT02706405 & 42 & I & $\begin{array}{l}\text { Fred } \\
\text { Hutchinson } \\
\text { Cancer } \\
\text { Research Center }\end{array}$ & $\begin{array}{l}\text { PD-L1 block } \\
\text { (durvalumab )/ CD19 } \\
\text { CAR }\end{array}$ \\
\hline
\end{tabular}




\begin{tabular}{|c|c|c|c|c|}
\hline NCT00889954 & 20 & I & $\begin{array}{l}\text { Baylor College } \\
\text { of Medicine }\end{array}$ & $\begin{array}{l}\text { HER2 CAR/dominant- } \\
\text { negative TGFbeta }\end{array}$ \\
\hline NCT02873390 & 20 & $\mathrm{I} / \mathrm{II}$ & $\begin{array}{l}\text { Ningbo Cancer } \\
\text { Hospital }\end{array}$ & $\begin{array}{l}\text { PD-1 antibody/EGFR } \\
\text { CAR }\end{array}$ \\
\hline NCT02862028 & 20 & I/II & $\begin{array}{l}\text { Shanghai } \\
\text { International } \\
\text { Medical Center }\end{array}$ & $\begin{array}{l}\text { PD-1 antibody/EGFR } \\
\text { CAR }\end{array}$ \\
\hline NCT03545815 & 10 & I & $\begin{array}{l}\text { Chinese PLA } \\
\text { General } \\
\text { Hospital }\end{array}$ & $\begin{array}{l}\text { CRISPR/Cas9-mediated } \\
\text { PD-1 } \\
\text { knockout/Mesothelin } \\
\text { CAR }\end{array}$ \\
\hline NCT02459067 & 8 & II & TC Biopharm & $\gamma \delta \mathrm{T}$ \\
\hline NCT03533816 & 38 & I & $\begin{array}{l}\text { University of } \\
\text { Alabama at } \\
\text { Birmingham }\end{array}$ & $\gamma \delta \mathrm{T}$ \\
\hline $\begin{array}{l}\text { NCT03608618, } \\
\text { CARMA }\end{array}$ & 15 & I & MaxCyte, Inc. & $\begin{array}{l}\text { Mesothelin macrophage } \\
\text { CAR }\end{array}$ \\
\hline NCT03056339 & 36 & $\mathrm{I} / \mathrm{II}$ & $\begin{array}{l}\text { M.D. Anderson } \\
\text { Cancer Center }\end{array}$ & $\begin{array}{l}\text { CD19 NK CAR, cord- } \\
\text { blood-derived }\end{array}$ \\
\hline NCT01974479 & 20 & I & $\begin{array}{l}\text { National } \\
\text { University } \\
\text { Health System, } \\
\text { Singapore }\end{array}$ & CD19 CAR NK \\
\hline NCT02944162 & 10 & I/II & $\begin{array}{l}\text { PersonGen } \\
\text { BioTherapeutics } \\
\text { (Suzhou) Co., } \\
\text { Ltd. }\end{array}$ & CD33 CAR NK \\
\hline NCT02742727 & 10 & I/II & $\begin{array}{l}\text { PersonGen } \\
\text { BioTherapeutics } \\
\text { (Suzhou) Co., } \\
\text { Ltd. }\end{array}$ & CD7 CAR NK \\
\hline NCT02892695 & 10 & $\mathrm{I} / \mathrm{II}$ & $\begin{array}{l}\text { PersonGen } \\
\text { BioTherapeutics } \\
\text { (Suzhou) Co., } \\
\text { Ltd. }\end{array}$ & $\begin{array}{l}\text { CD19 CAR NK, NK- } \\
\text { 92-derived }\end{array}$ \\
\hline NCT00995137 & 14 & I & $\begin{array}{l}\text { St. Jude } \\
\text { Children's } \\
\text { Research } \\
\text { Hospital }\end{array}$ & CD19 CAR NK \\
\hline NCT03415100 & 30 & I & $\begin{array}{l}\text { The Third } \\
\text { Affiliated } \\
\text { Hospital of } \\
\text { Guangzhou } \\
\text { Medical } \\
\text { University }\end{array}$ & G2D CAR NK \\
\hline NCT02839954 & 10 & $\mathrm{I} / \mathrm{II}$ & $\begin{array}{l}\text { PersonGen } \\
\text { BioTherapeutics }\end{array}$ & MUC1 CAR NK \\
\hline
\end{tabular}




\begin{tabular}{l|l|l|l|}
\hline & & $\begin{array}{l}\text { (Suzhou) Co., } \\
\text { Ltd. }\end{array}$ \\
$\begin{array}{l}\text { NCT02735083, 200 } \\
\text { UCART19 }\end{array}$ & I & $\begin{array}{l}\text { Institut de } \\
\text { Recherches } \\
\text { Internationales } \\
\text { Servier }\end{array}$ & $\begin{array}{l}\text { CD19 CAR, RQR8, } \\
\text { allogeneic }\end{array}$ \\
\hline $\begin{array}{l}\text { NCT03190278, 162 } \\
\text { UCART123 }\end{array}$ & I & Cellectis S.A. & CD123 CAR, allogeneic \\
$\begin{array}{l}\text { NCT03018405, 146 } \\
\text { THINK, } \\
\text { CYAD-01 }\end{array}$ & I/II & Celyad & $\begin{array}{l}\text { CAR-T, expressing NK } \\
\text { activating receptor } \\
\text { NCT03612739, 15 }\end{array}$ \\
$\begin{array}{l}\text { EPITHINK } \\
\text { CINR CART) }\end{array}$
\end{tabular}

